\title{
A study on a polygeneration plant based on solar power and solid oxide cells
}

\author{
Ullvius, Nicolás Cobos; Rokni, Masoud
}

Published in:

International Journal of Hydrogen Energy

Link to article, DOI:

10.1016/j.ijhydene.2018.04.085

Publication date:

2019

Document Version

Peer reviewed version

Link back to DTU Orbit

Citation (APA):

Ullvius, N. C., \& Rokni, M. (2019). A study on a polygeneration plant based on solar power and solid oxide cells. International Journal of Hydrogen Energy, 44, 19206-19223. https://doi.org/10.1016/j.ijhydene.2018.04.085

\section{General rights}

Copyright and moral rights for the publications made accessible in the public portal are retained by the authors and/or other copyright owners and it is a condition of accessing publications that users recognise and abide by the legal requirements associated with these rights.

- Users may download and print one copy of any publication from the public portal for the purpose of private study or research.

- You may not further distribute the material or use it for any profit-making activity or commercial gain

- You may freely distribute the URL identifying the publication in the public portal

If you believe that this document breaches copyright please contact us providing details, and we will remove access to the work immediately and investigate your claim. 
In press in International Journal of Hydrogen Energy,

https://doi.org/10.1016/j.ijhydene.2018.04.085.

\title{
A Study on a Polygeneration Plant based on Solar Power and Solid Oxide Cells
}

\author{
Nicolás Cobos Ullvius and Masoud Rokni* \\ Technical University of Denmark, Mechanical Department, Copenhagen 2800, Denmark \\ *Corresponding author: MR@ mek.dtu.dk
}

\begin{abstract}
While energy demand in this fast developing world is increasing, its future is being compromised by the $\mathrm{CO}_{2}$ emissions produced through the burning of fossil fuels. Clean energy technologies are available, but there are still barriers hindering their full integration into the society, the majority of which are economic and social. For these reasons, the development of new technologies and configurations to make renewable energies systems more cost-effective is urgently needed. The plant design proposed in this paper consists of basic Dish-Stirling collectors supported by a reversible solid oxide fuel cell acting as a power generator and storage unit, and therefore offering dispatchable power on demand. Further, the system reuses the waste heat for seawater desalination, which is very convenient for arid areas with high solar radiation and shortage of freshwater. The present work is an analytical study in which thermodynamic investigation of the performance evaluation of a selfsustainable polygeneration system with integrated hydrogen production, power generation, and freshwater production is conducted. An evaluation in a real context (South Africa) showed the potential of this system to supply $500 \mathrm{~kW}, 24 \mathrm{~h}$ a day, while producing a considerable amount of freshwater. Although the distillation system presented is able to produce 8464 liters per day, there is potential for it to increase its output by nine times or more.
\end{abstract}

Keywords: Solar energy, RSOC, Dish-Stirling, PTSC, Hydrogen, Desalination, Electrolyze

\section{Introduction}

Owing to global warming and its consequences, renewable energy production technologies will be called to play a significant role in the immediate future. Therefore, it is essential to find new, effective solutions that allow for the integration of sustainable energy production techniques into the current existing systems, thereby decreasing dangerous emissions. Energy policies moderate such transitions, and ensure that a specified threshold is met. However, it is desirable that such transitions occur in harmony with the present socioeconomic situations and that they utilize current technological achievements in clean energy production. Further, it is key that these solutions are cost-effective and can be used for polygenerations purposes such as electricity, fuel and freshwater production. In this way, the negative impacts on global emissions decreases significantly. In such designs, direct electricity, heat and freshwater can be generated from a renewable source, such as solar energy, when the source is available. Electrolysis technology such as solid oxide electrolyte cell (SOEC) can be used to store the excess energy in fuel form when the renewable source is high enough. The stored fuel can then be used to generate heat, power and freshwater by a solid oxide fuel cell (SOFC) when the renewable source is low, such as during nighttime when using sun energy or on a calm day when using wind energy. This implies that there is a need for a reversible solid oxide cell (RSOC) that can produce synthetic fuel from electricity, or produce electricity from fuel when reversed.

Sun energy may play an important role in the future of power plants for multi-generation products. Plant performance (energy efficiency) increases with polygeneration systems. The waste heat from the system can be used to produce heat, cool, freshwater, fuel production, etc. (besides electricity). Owing to the common nature of fluctuation in energy (or other renewable sources), most of these plants can benefit from an additional storage unit. With that, renewable energy plants could provide dispatchable power, enabling stand-alone systems for facilitating the grid operation. 
Several studies on RSOC systems have been conducted; for example, [1] reviewed technological development of hydrogen production from an SOEC system in terms of materials, cell configuration designs, electrode depolarizations and mathematical modeling. [2] presented the exergoeconomic analysis of a hybrid system based on steam biomass gasification for hydrogen production. [3] showed the feasibility of the concept and successful reversible operation of a dual cell through electrochemical tests carried out by impedance spectroscopy. [4] carried out an experimental study to demonstrate the heat spreading capabilities and power limitations of high-temperature applications in SOEC/SOFC stacks.

Parabolic trough solar water heating is a well-proven solar energy technology that is being used on a commercial scale. High-temperature parabolic trough solar collector (PTSC) systems are currently operating in solar electric generating systems. For example, [5] conducted thermal simulation of a PTSC to estimate the transient performance of a solar industrial water heating system. [6] developed a mathematical model for PTSC and compared the results with experimental data, finding a small percent error. [7] designed and experimentally validated an adsorption icemaker driven by PTSC, and integrated it with a sensible thermal storage tank successfully. [8] experimented on innovative flat aluminum absorbers for process heat and direct steam generation in small PTSC systems.

Direct contact membrane distillation (DCMD) is a thermal separation process where only the water vapor (or other volatile) passes through a micro-porous hydrophobic membrane while impurities, such as salt, cannot cross the membrane. The vapor pressure gradient created by the temperature difference between both sides of the membrane drives the process. In 2000, [9] reviewed the desalination of seawater by the DCMD system, and its performance from laboratory scale to pilot projects. [10] showed experimentally that $99.99 \%$ of salt can be separated from hot water at $80{ }^{\circ} \mathrm{C}$ in optimum conditions and with optimum membrane material selection. Desalination powered by solar energy is an attractive solution that can address the worldwide water-shortage problem without contributing significantly to greenhouse gas emissions. It is worth noting that often there is shortage of fresh water where solar radiation is high. As deliberated in [11], a promising system for renewable energy desalination is the utilization of low-temperature DCMD systems. The study by [12] showed that experimental data agreed very well with the calculated results in terms of vapor mass flux, as well as membrane and total heat transfer coefficients. In addition, such a technique has a great advantage because it works at lower temperatures, even down to $40{ }^{\circ} \mathrm{C}$, which allows it to use lower temperatures sources and avoid the great latent heat of water [13].

Akikur et al. [14] studied a RSOC with photovoltaic (PV) to design a possible future power plant using solar energy that can produce electricity at any time of the day, for example, at night. However, they did not use the dissipated heat from the system, but recommended that it is crucial to develop a management plan/scheme that takes into account the forecast solar radiation, the energy demand, and the stored fuel supplies. Combination of PVs with other types of electrolysers and electrolysers with Rankine cycles for hydrogen has also been studied in the literature, see e.g. [15], [16] and [17].

In this work, a poly-generation system is presented that uses a Dish-Stirling engine to convert solar irradiation into electricity and drive an RSOFC. Further, the waste heat is recovered for seawater distillation through a DCMD technique. Such a system will result in a self-sufficient and flexible poly-generation plant driven by solar power only that can be regulated for different output combinations of hydrogen, electricity, heat and freshwater. A complete balance of plant is first designed, and then the performance of the system is analyzed thermodynamically for some scenarios. This paper assesses the capacity of such plants to generate continuous and reliable power, and freshwater at the same time.

To the best of the authors' knowledge, no similar studies exist in the open literature. Therefore, this study may provide some inspiration for further analysis and perhaps implementation of such technology into current existing systems. The objective of the present is not to study the cost of the system but present an attractive system which might be of interest for the future power generations.

\section{Plant Model}


From the block chart in Figure 1, it can be seen that the plant delivers power to the grid by transforming the solar energy collected by the Dish-Stirling system. Further, the system is supported by the RSOFC in order to overcome the fluctuating nature of the solar radiation. The idea is that the Dish-Stirling delivers part of its load to the RSOFC for storage; this load is used to produce fuel (hydrogen) during the peak hours of radiation (SOEC mode). Then during low or zero radiation, the produced fuel is used to feed the RSOFC and can still cover the power demand (SOFC mode). At the same time, most of the heat produced by the system is used for seawater desalination. Furthermore, a parabolic trough solar collector (PTSC) that uses solar energy is used to generate steam for the system.

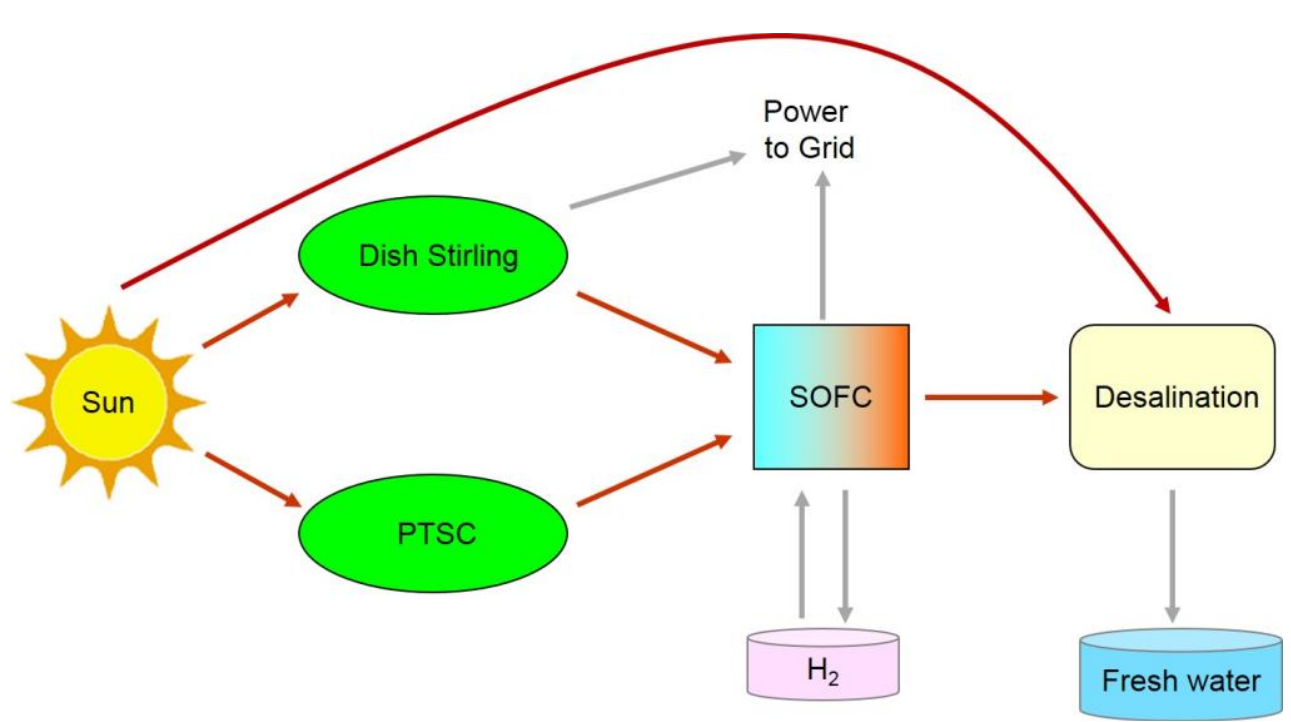

Figure 1. Block chart representing energy flow in the plant

The efficiency of such a system will be accounted for by considering the sun radiation as input, and the fresh water, power to the grid, and net balance of $\mathrm{H}_{2}$ produced as output. The system runs in different modes during the day; therefore, the overall efficiency will be defined by total numbers at the end of one cycle (for example $24 \mathrm{~h}$ ). The amount of fresh water in terms of energy is defined as the energy needed to evaporate the same amount of seawater from its initial state (assumed at $15^{\circ} \mathrm{C}$ ), which is around $670 \mathrm{~kJ} / \mathrm{kg}$.

$$
\eta_{\text {system }}=\frac{\text { Freshwater }+ \text { POWER }+L H V_{\text {Hydrogen }} H_{2, \text { net production }}}{\text { Solar Power on Collectors }}
$$

Such a definition for efficiency helps researchers to compare similar systems with each other and to approximate the energy flow, but it should be noted that solar energy is a free resource and therefore cannot be considered as an economic parameter. However, such definition may help researchers to improve plant performance in terms of production (net electricity, cooling, heating, freshwater, etc.). On the other hand, materials, installation, and operation costs are incurred; for this reason, a deeper techno-economical study would be a good complement to this study.

Before explaining the plant's operation in detail, a description of the models for the main components is provided in the sections that follow.

\subsection{RSOFC}

Two different sub-models represent each operation mode: Electrolysis (SOEC) and fuel cell (SOFC).

\subsubsection{SOFC}


The SOFC model used in this study is the same as that in [14]. It is a zero-dimensional model, which calculates the outlet gases composition based on equilibrium; furthermore, the power produced is calculated using a detailed electrochemical model calibrated with experimental data. The data were taken for gas temperatures between $650-800{ }^{\circ} \mathrm{C}$; thus, this was the limiting range for the operating temperatures in the present study, as well. The efficiency of this component is defined as

$$
\eta_{\text {el_SOFC }}=\frac{P O W E R}{L H V \cdot \dot{m}_{H 2, \text { inlet }}}
$$

where $\dot{m}_{H 2 \text {,inlet }}$ is the mass flow of the fuel into the plant.

A comparison between the SOFC model used here and the experimental data is shown in [18] in terms of current density and cell voltage (IV curve). The model captures the experimental data very well at four different cell operating temperatures from $650{ }^{\circ} \mathrm{C}$ to $800{ }^{\circ} \mathrm{C}$.

\subsubsection{SOEC}

This model is based on the model presented by [19] and [20], which also contain a detailed electrochemical model, and captures the experimental data very well. First, pressures at the gas outlets are simply calculated using the input parameters as follows:

$$
p_{c a \_ \text {out }}=p_{c a_{\text {in }}}\left(1-d p_{c a}\right) \quad p_{a n_{-} \text {out }}=p_{a n_{\text {in }}}\left(1-d p_{a n}\right)
$$

where $d p_{a n}$ and $d p_{c a}$ are the relative pressure drops at the anode and cathode sides, respectively. Then, the cell voltage and the current density are calculated using the power input.

$$
P_{\text {SOEC }}=N_{\text {stack }} N_{\text {cell }} E_{\text {cell }} A_{\text {cell }} J
$$

where $N_{\text {stack }}, N_{\text {cell }}, E_{\text {cell }}, A_{\text {cell }}$ and $J$ are the number of stacks, number of cells per stack, cell voltage, single cell area and current density, respectively. The Nernst potential gives the theoretical minimum electrical work, but in reality, part of the voltage is lost irreversibly owing to polarizations such as ohmic, activation, and concentration polarizations. The ohmic resistance remains constant while the other two vary depending on the current applied, i.e., ohmic polarization increases proportionally with the current, while activation polarization and concentration polarization are dominant at low and high current levels, respectively [19]. Thus, the minimum electrical work that has to be applied to the SOEC is determined by the Nernst potential plus the polarization losses. The cell voltage is defined by determining the Nernst voltages $\left(E_{\text {Nernst }}\right)$ as follows:

$$
E_{\text {cell }}=E_{\text {Nernst }}+\Delta E_{\text {act }}+\Delta E_{\text {ohm }}+\Delta E_{\text {conc }}
$$

The Nernst potential and the polarizations in the SOEC (activation, ohmic and concentration) are calculated as explained in [19] and [21]. The diffusion coefficient is approximated using the kinetic theory and the Chapman-Enskog theory [22].

Note that the energy applied through electrical work might not be enough to drive the system's unspontaneous reactions. The remaining energy is then applied by a heat source at higher temperature and/or by directly increasing the power (increasing the current through the cells), which in turn produces more heat owing to the Joule effect [23]. When the heat produced equals the heat demand in the reaction (thermo-neutral point), then the voltage becomes

$$
E_{\text {thn }}=\frac{\Delta_{r} H}{2 F}
$$
where $\Delta_{r} H$ is the enthalpy change in the reactions, and $F$ is the Faraday constant $(96485.34 \mathrm{C} / \mathrm{mol})$.

The outlet concentrations and mass flows can be determined by molar balance of each element and using the current density to determine the quantity of reactions taking place. The molar 
production of $\mathrm{H}_{2}$ (or moles of $\mathrm{H}_{2} \mathrm{O}$ molecules split) is fixed for a certain current value; consequently, $\mathrm{O}_{2}$ is produced according to the reaction

Note that the power, the voltage and the current are dependent on each other; therefore, if one of them is defined, the others can be determined. Another way of defining these parameters would be by fixing the $\mathrm{H}_{2}$ production or fixing the molar fraction at the outlet.

Finally, the efficiency is defined as

$$
\eta_{S O E C}=\frac{L H V \cdot \dot{m}_{H 2, o u t}}{P O W E R+Q_{\text {in }}}
$$

where $P O W E R$ and $Q_{i n}$ are the electrical power required to run the electrolyzer and the heat input required to preheat the water, while $\dot{m}_{H 2, \text { out }}$ is the mass flow rate of hydrogen production.

[21] and [20] discussed the validity of the model with experimental data in terms of energy efficiency and $\mathrm{H}_{2} \mathrm{O}$ conversion for different current densities and at different operating temperatures.

\subsection{DISH-STIRLING}

This model consists of two different parts: the solar dish collector and the Stirling engine. The Stirling model is adopted from the model presented in [24] and is based on a pseudo-Stirling cycle, which provides better agreement with engine performance data. Stirling engines are noted for their quiet operation and the ease with which they can be connected to almost any heat source. In this case, the engine is connected to a heat source of a solar collector. On the other hand, the collector system that is in charge of providing heat to the engine is inserted on top of the Stirling model. Details regarding the engine model can be found in [25] and therefore the equations are not presented in this paper. The collector model is, however, presented below, starting from equation (11). First, the heat supplied to the Stirling is determined by calculating the total efficiency of the solar collector, including the concentrator dish and the receiver.

$$
Q_{\text {high }}=S \cdot A_{\text {conc }} \cdot N_{\text {unit }} \cdot \eta_{\text {conc }} \cdot \eta_{\text {rec }}
$$

where $S$ is the direct solar radiation per area, $A_{\text {conc }}$ is the area of the concentrator, $N_{\text {unit }}$ is the number of units, $\eta_{c o n c}$ is the concentrator efficiency, and $\eta_{r e c}$ is the receiver efficiency. The optical efficiency of the dish concentrator is assumed to be constant (including reflectivity and interception factor) while the receiver efficiency is modeled taking into account the heat losses [26] as

$$
\eta_{r e c}=\alpha \tau-\frac{U_{C C}\left(T_{r e c}-T_{a m b}\right)+\varepsilon \sigma\left(T_{r e c}^{4}-T_{s k y}^{4}\right)}{\eta_{c o n c} C_{R} S}
$$

where $\varepsilon$ is the emissivity of the receiver, $\sigma$ is the Boltzmann constant $\left(5.67 \times 10^{-8} \mathrm{~W} /\left(\mathrm{m}^{2} \mathrm{~K}^{4}\right)\right)$, and $C_{R}$ is the concentration ratio. $T_{r e c}, T_{s k y}$ and $T_{a m b}$ are the receiver, sky and ambient temperatures, respectively. $\alpha$ and $\tau$ are absorptance and transmittance, respectively, and are assumed to be constant. As a result, the model does not take into account the performance variation due to solar incidence angle variations $\left(K_{\gamma \tau \alpha}=1\right)$. However, the error (if present) will be insignificant/negligible because the full tracking system is usually quite accurate, which diminishes the error (if any). Further, since there is no cover, the value for transmissivity, as well as absorptivity, would be close to one, which is the maximum possible. The $U_{C C}$ is the combined convection-conduction heat loss coefficient accounting for convection to the ambient environment and conduction through the structure. This is defined in Appendix B. 
The mechanical power of the Stirling engine as well as other parameters are assumed according to [24]. Table A1 (in Appendix A) provides the specifications for the Dish-Stirling, while Appendix B presents more details about modeling of this component.

Finally, it worth noting that the Stirling engine model used in this study is a pseudo Stirling cycle,

\subsection{PTSC-SG (Steam Generator)}

A model for the steam generator PTSC is developed by combining the models presented in [23], [27], [28], [29], [30]. In short, the model calculates the outlet steam state conditions from the water flow inlet and the external atmospheric conditions. The model includes calculations of heat losses and pressure drops along the pipe. The input parameters are the direct solar radiation, solar ray's angle of incidence, wind velocity, ambient temperature, sky temperature, the number of rows and the length. Other dimensions and optical characteristics of the unit, such as pipe aperture $(w)$, receiver diameter $(D)$, reflectivity $(\rho)$ and absorptance $(\alpha)$, are also included in the model. The model equally distributes the total incoming mass flow between the numbers of rows. Then, it divides the receiver into three sections depending on the water state, i.e., whether the water is liquid, saturated, or steam, as displayed in Fig. 2, as different water states have different properties and behaviors.

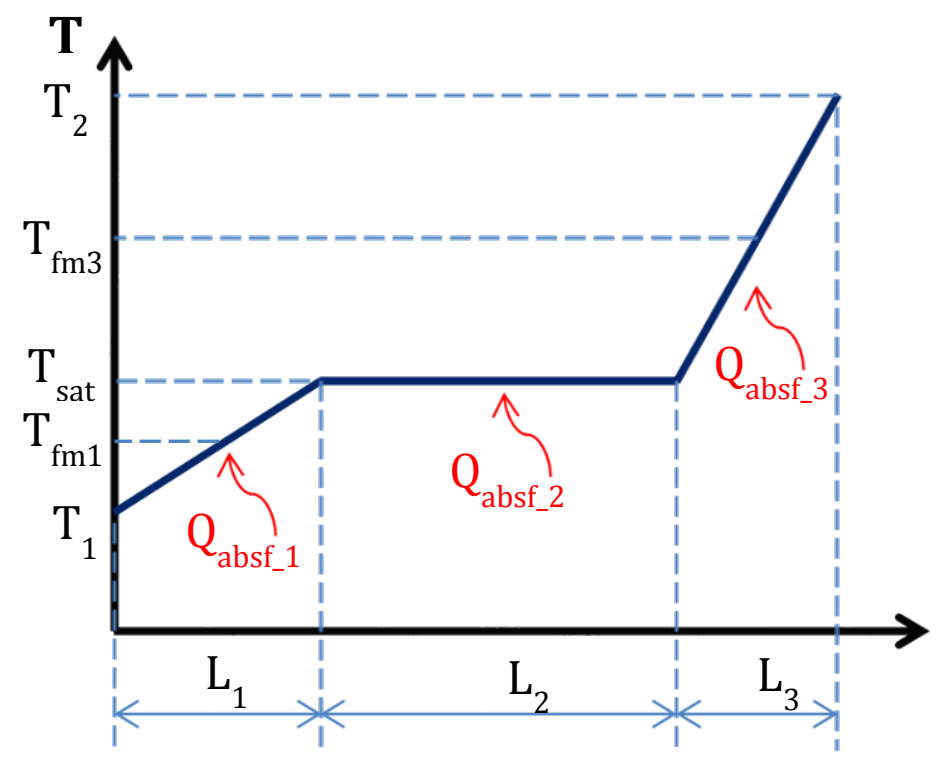

Figure 2. Qualitative temperature distribution along the pipe of the PTSC.

First, the model calculates the outlet pressure as

$$
p_{\text {out }}=p_{\text {in }}-\Delta p=p_{\text {in }}-\Delta p_{1}-\Delta p_{2}-\Delta p_{3}
$$

where $\Delta p_{1}, \Delta p_{2}$ and $\Delta p_{3}$ are the pressure drops at different sections. Thus, the total pressure drop along each tube would be the sum of the pressure drops in each section. For the single-phase flow (section 1 and 3), the pressure drop is calculated by the Darcy-Weisbach correlation [31], equation (14). The Colebrook correlation, equation (15), defines the friction coefficient $(f)$ as

$$
\Delta p_{s}=f_{s} \rho_{m, s} \frac{V_{m, s}^{2}}{2 D_{r i}} L_{s} \quad s=1 \text { and } 3
$$




$$
\frac{1}{\sqrt{f_{s}}}=-2 \log _{10}\left(\frac{r_{r}}{3.7}+\frac{2.51}{\operatorname{Re} \sqrt{f_{s}}}\right) \quad s=1 \text { and } 3
$$

where $\rho_{m, s}$ and $V_{m, s}$ are the average density and velocity of the flow in the section $s$, respectively, and $D_{r i}$ is the inner diameter of the receiver. The relative roughness $r_{r}=\delta / D_{r i}$, where $\delta$ is the absolute roughness of the pipe material. For example, the absolute roughness for stainless steel is $1.5 \times 10^{-5} \mathrm{~m}$ ( see [32]). It is important to mention that the pressure drop in the first section will define the saturation pressure, and therefore, the saturation temperature will also be known. However, the length of the first section must be determined first by determining the heat demand.

In the second section, as there is a boiling flow where the two phases coexist, the pressure drop is calculated differently by using the Friedel correlation [30] using data from [34], see Appendix C for more details.

Regarding the heat transfer, the flux balance represented in Fig. 3 is characterized through the equation below:

$$
Q_{\text {absf }, s}=\eta_{\text {opt }} \cdot S \cdot A_{\text {cons }, s}-U_{L} \cdot A_{\text {rec }, s}\left(T_{\text {rom }, s}-T_{a m b}\right) \quad \mathrm{s}=1,2 \text { and } 3
$$

where $Q_{a b s f, s}$ is the heat absorbed by the fluid in section $s, \eta_{o p t}$ is the optical efficiency, $S$ is the irradiation, $T_{a m b}$ is the ambient temperature, $T_{r o m, s}$ is the mean temperature at the outer surface of the receiver in section $s$, and $U_{L}$ is the mean heat transfer coefficient for the entire PTSC. The area of the concentrator in section $s$ is defined as $A_{\text {cons,s }}=$ aperture $\cdot L_{s}$, and similarly, the receiver area in the corresponding section is $A_{r e c, s}=\pi D_{r o} L_{s}$. Appendix $\mathrm{C}$ presents the detailed modeling of this component.

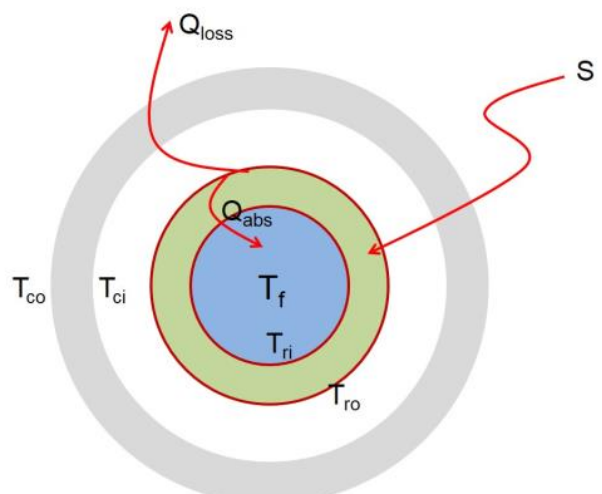

\section{$2.4 D C M D$}

For this component, a hollow fiber configuration is chosen, as described in [32](see Fig. 4). The warm seawater flows in the fibers (the feed side), while cold water flows through the permeate side, which is located at the other side of the fibers. The design is made in such a way that both sides have a constant flow. Owing to the counter-flow configuration, the temperature difference along the fiber is almost constant and therefore is the associated vapor pressure difference. The pressure gradient across the membrane is the force that drives the entire process. The modeling along the fiber is performed by dividing the fiber into smaller segments or volumes of control, and applying the balance equations (mass flow and energy) using the mean properties of the segment and the state of each segment (temperature, density, pressure, etc.). Note that if the system is not discretized, then the nonlinear behavior of the system leads to large errors in the results. 


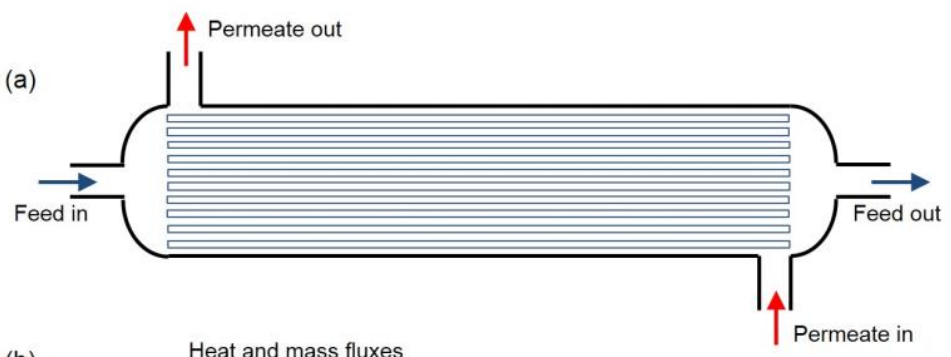

(b)

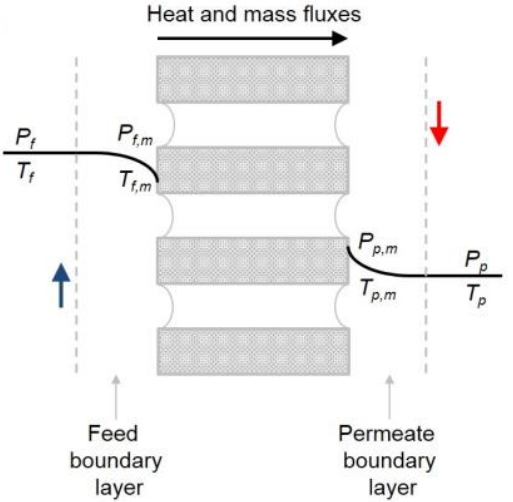

(c)

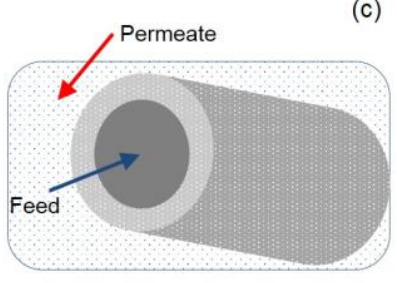

Figure 4. Scheme of a) a hollow fibers module and b) the mass and heat transfer through the membrane c) cross section.

The range of operation of the model for the mass flow of one unit is between $0.05-0.15 \mathrm{~kg} / \mathrm{s}$; however, higher values can also be applied. In such cases, the model calculates the needed number of units. The range of operation for the feed temperature has limits, and in this study, it is set between $70{ }^{\circ} \mathrm{C}$ to $90{ }^{\circ} \mathrm{C}$. The permeate flow is assumed to remain at a constant in-flow of $0.1 \mathrm{~kg} / \mathrm{s}$ in each unit and at $25^{\circ} \mathrm{C}$ at the inlet.

Another important issue to consider, when designing the hollow fiber operation, is the membrane liquid entry pressure (LEP), which sets the limit for the applied transmembrane pressure. Transmembrane pressure is defined as the hydrostatic pressure minus the vapor pressure $\left(p_{p, m}-p_{p}\right.$ and $\left.p_{f}-p_{f, m}\right)$. Values below such limits will prevent liquid from entering the pores. Note that the hydrostatic pressure does not affect the permeate flux, but it is important to consider, as it prevents the pores from flooding. The detailed mathematical model for this component is explained in [35]. Table A3 (in the appendix) shows the important data for the DCMD used in study.

\section{Plant Configurations}

In short, the plant produces electricity and fresh water at all times by converting the solar energy collected regardless of the time of day. A Dish-Stirling delivers part of its load to the dual mode SOFC (RSOFC), which load is used to produce fuel (hydrogen) during the peak hours of radiation (SOEC mode), and then uses the fuel produced to feed the RSOFC during low or zero radiation (SOFC mode). Thus, the plant is able to cover the power demand all the time, and at the same time, it produces fresh water through seawater desalination.

For successful plant operation, it is crucial to develop a management schedule/plan that takes into account the forecast solar radiation, energy demand and fuel supply. The flexibility of the plant in producing power and fresh water will be improved greatly if the schedule is correctly planed. This has been a limitation of many renewable energy plants.

As highlighted above, the plant has two modes of operation: the SOEC and SOFC modes. The plant's operation differs slightly from the SOEC mode to the SOFC mode, as shown in Fig. 5 and Fig. 6. The operation of the system in SOEC mode is explained in detail first.

\section{SOEC mode}

1. Water from the tank (point 1 in Fig. 5) is pumped to the PTSC (point 2), where it is heated, 
2. The steam is then divided into two flows. Part of the steam goes to the RSOFC (point 4), and its quantity is regulated according to the electricity surplus from the Dish-Stirling units (point 212). The rest of the steam (point 11) is sent to a heat exchanger (SWP1) to preheat seawater (from point 41 to point 42) before it is sent to the separator (point 12).

3. Before the steam goes (point 4) to the RSOFC, it flows through a cathode preheater (CP) to gain heat (point 5) from the cathode off-fuel of the RSOFC (point 6). The operating temperature of the cells is assumed to be $750{ }^{\circ} \mathrm{C}$, and the steam is preheated to approximately $600{ }^{\circ} \mathrm{C}$.

4. Preheated steam (5) is fed to the cathode side of the RSOFC. Owing to steam electrolysis, the cathode outlet (point 6) contains a mixture of hydrogen and water, and the anode outlet (point 8) contains oxygen. Both outlets are assumed to have the same temperature as the cell operating temperature $\left(750{ }^{\circ} \mathrm{C}\right)$.

5. The off-fuel $\left(\mathrm{H}_{2}+\mathrm{H}_{2} \mathrm{O}\right)$, after leaving the cathode pre-heater (point 9), is cooled again in another heat exchanger (SWP2) to preheat the seawater (from point 42 to 43). The thermodynamic state at the outlet (point 10) is designed to be slightly above the saturation temperature of water.

6. Later in the separator (condenser), the water in the off-fuel mixture (point 10) condenses and mixes with corresponding condensed water at point 12, allowing for the collection of water at the bottom of the condenser (point 13) and $\mathrm{H}_{2}$ from the top (point 14) at ambient temperature. Water is stored at ambient pressure, while the hydrogen is pressurized and stored (point 15) using the compressor $\mathrm{C} 2$ (min pressure of 1.5 bar).

7. On the other hand, the oxygen coming out of the anode side (point 8) preheats the seawater in a heat exchanger (SWP3) before it is released into the atmosphere (point 46 to 47).

8. The seawater is preheated to $80^{\circ} \mathrm{C}$ (at both 43 and 47) using the heat released from the RSOFC outlets, and then are mixed together. The resulting flow (point 50) is used to feed the DCMD system. The outlet is then discharged to the surrounding environment (point 51). On the permeate side, fresh water is leaves the tank (point 53) and flows into the DCMD. The outlet (point 54) is used to preheat seawater (point 45 to 46) in a heat exchanger (SWP4) before the water moves to the next heat exchanger (SWP3). Finally, the fresh water out of SWP4 is returned to the tank at ambient pressure.

9. Pumps 2, 3 and 4 drive the distillation system taking into account the liquid entry pressure limits.

10. At the same time, the Dish-Stirling system produces power (point 210) for supplying electricity to the RSOFC, while the remaining power is sent to the grid. As the power generated in the Dish-Stirling is AC, and the RSOFC works with DC (point 211), a rectifier is used between these components.

The system is set in such a way that the RSOFC in the electrolyzer mode is working at the thermoneutral point (or slightly over) by controlling the steam and the power supplied. Under such operating conditions, minimum power is required by the system and an external heat source (at such high temperature level) is not necessary, see e.g. [36].

Regarding the storage system, hydrogen is stored at higher pressure while water is not because the energy required to compress a gas is much higher than the energy required to compress a liquid. Therefore, to discharge $\mathrm{H}_{2}$ at ambient pressure and then compress it again would result in energy wastage. However, in the case of the water, it is justified because the wasted energy is minimal when compared to the greater complexity associated with storing pressurized water. It shall be noted that pressurized ROEC has also been studied and validated experimentally, see e.g. [37].

Further, it is important to keep in mind that the flow entering the separator (point 12) has to be at a temperature that is higher than the condensing temperature of water. Then, the separator will release heat until both water and $\mathrm{H}_{2}$ are at ambient temperature and completely separated in two phases. In order to achieve this, the temperature at point 12 should be the condensing temperature, and the pump 
P1 must deliver the necessary pressure. In this way, the gas state at point 12 is assured. It is also worth

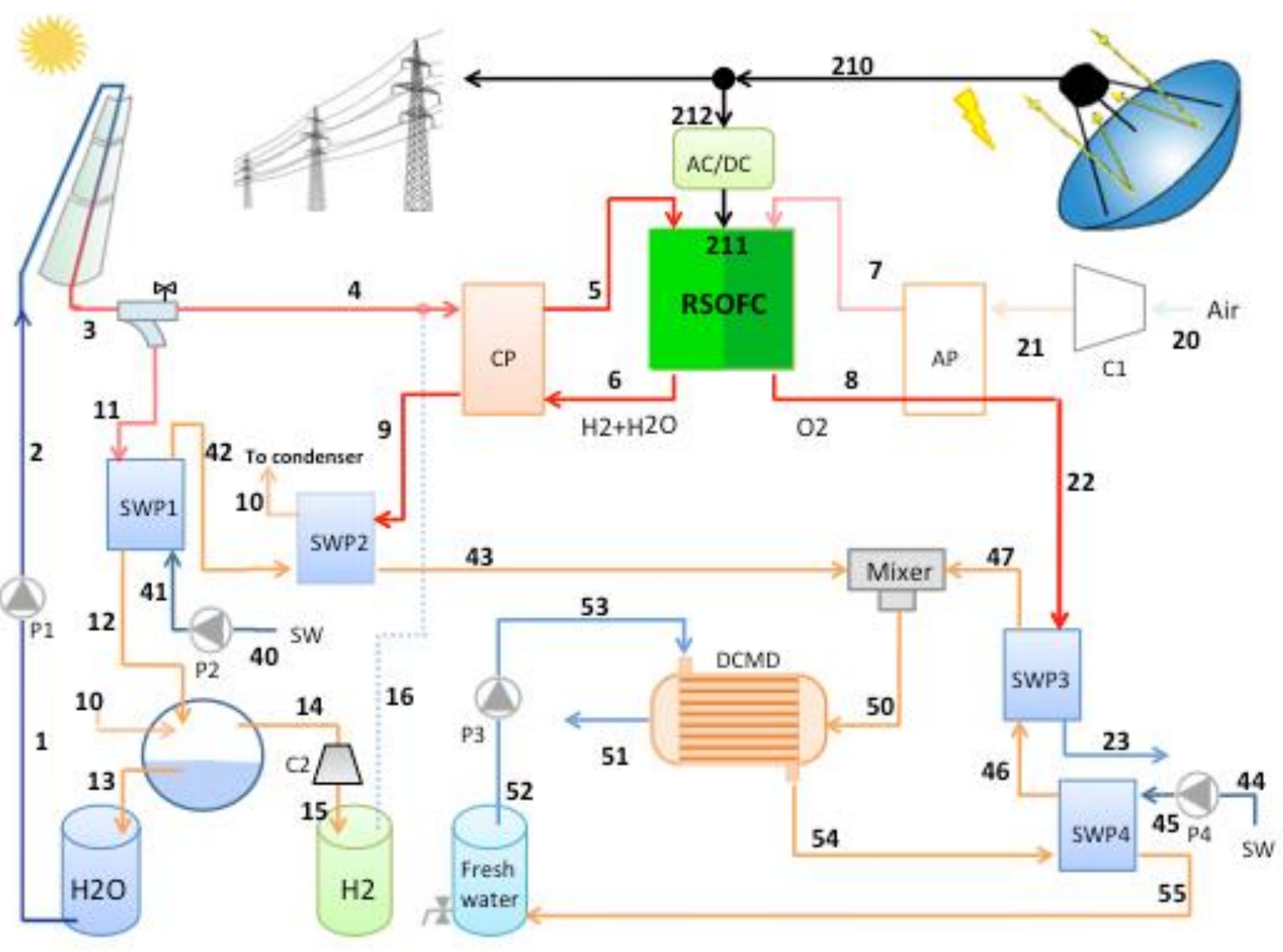

Figure 5. Scheme of SOEC mode operation.

\section{SOFC mode}

1. The heat exchanger, which was a cathode preheater in SOEC mode, is now an anode preheater, and the heat exchanger, which was anode preheater in SOEC mode, is now a cathode preheater. In SOFC mode, the stored $\mathrm{H}_{2}$ (point 16) feeds the anode preheater.

2. A blower (C1) supplies air to the cathode side of the SOFC (point 21). Pressure drops along the air pass-way decide the pressure of the air after it leaves the blower. A heat exchanger (AP) preheats the air before it enters the cathode side of the SOFC (point 7). Off-air out of the cathode (point 8 ), which is approximately $150{ }^{\circ} \mathrm{C}$ warmer, preheats the incoming air.

3. The reactions taking place in the RSOFC are now reversed. As a result, the off-fuel at the anode outlet (point 6) will be composed mostly of water and hydrogen, while the off-air at the cathode outlet (point 8) will be composed of air that is poor in oxygen.

4. In this mode, all the steam generated at the PTSC (point 11) is used to feed the heat exchanger (SWP1) and preheat the seawater (from point 41 to 42 ).

5. The Dish-Stirling system is still producing power, but less than in the SOEC mode, owing to less radiation. However, the RSOFC is now able to produce power (point 211) using the stored fuel. An inverter converts the power of the RSOFC from DC to AC and sends it to the grid (point 212). 


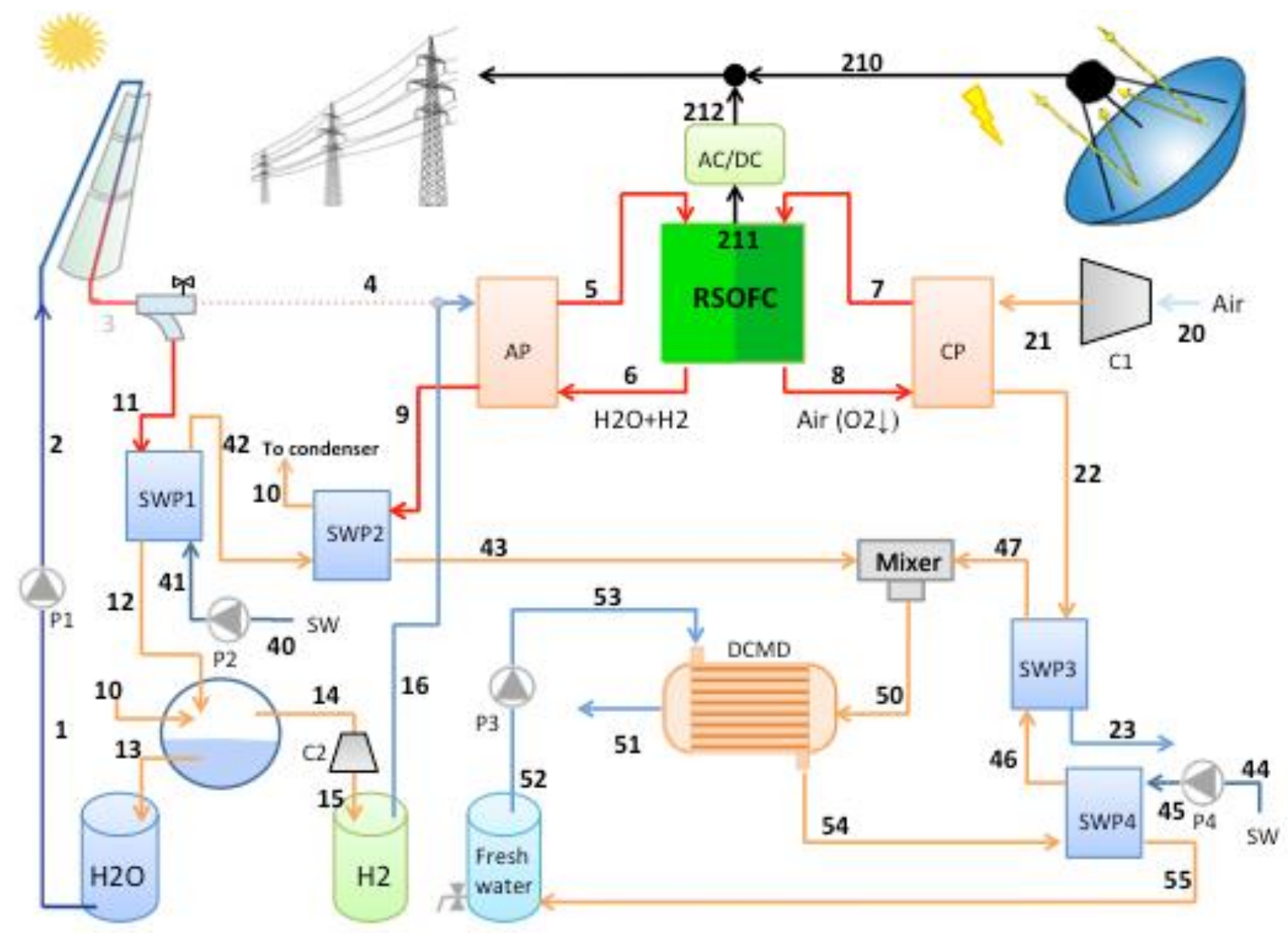

Figure 6. Scheme of SOFC mode operation.

\subsection{Design, sizing and dimensioning methodology}

There are two main subsystems in the plant: the Dish-Stirling collectors and the storage system. Both can be relatively easy to scale up by adding more collector units or solid oxide cell stacks, respectively. One can optimize the size of these subsystems and achieve a reliable power supply by estimating the power demand during the daytime. First, it is necessary to make sure that the main component of the storage system (the RSOFC) can deliver the maximum demanded power. Once a minimum RSOFC size is set, one should look at the performance and needs of the RSOFC when the system is operating in electrolysis mode, such as the power and mass flow of steam at a fixed temperature. Afterwards, one needs to define the number of rows and length of the PTSC, as well as the number of Dish-Stirling units, by taking into account the solar radiation in order to meet the SOECs power demand at any time. Note that the Dish-Stirling units need to cover not only the SOEC demand but also the power demand through the grid.

The next step is to evaluate the system against an estimated solar irradiation profile, in order to check whether the system is self-sufficient, meaning that the net balance of hydrogen is positive (production versus usage). If not, then the size of the RSOFC needs to be increased to produce more hydrogen. This, in turn, means that one needs to increase the number of Dish-Stirling units. On the other hand, in order to ensure that steam is not condensing before reaching the condenser (point 12), one needs to set the minimum temperature at point 2 as the saturation temperature, which is approximately $180^{\circ} \mathrm{C}$.

The pressure drops should also be taken into account in the system design. Pump 1 (P1) is in charge of driving the water and associated pressure drops along its way until the condenser, therefore its pressure supply must be sufficient. This pressure should not be too high either, as the higher the pressure is, the higher the temperature of condensation will be, and therefore less heat will be available for seawater preheating at point 9 . In addition, the pressure in the distillation system should 
also be considered. Pump 3 (P3) has to provide enough pressure to overcome the pressure losses in the DCMD and SWP4 before the water reaches the fresh water tank. At the same time, the DCMD operation limits the membrane liquid entry pressure and therefore the possibility to recover the heat at the outlet of the permeate side is then conditioned by the pressure drop in the heat exchanger (SWP4).

\subsection{Input parameters}

Table A1 through Table A3 in the appendix present the most relevant parameters used to model each component (Dish-Stirling, PTSC and DCMD). The ambient conditions are assumed to be $30{ }^{\circ} \mathrm{C}$ for air temperature, $20^{\circ} \mathrm{C}$ for sky temperature and $5 \mathrm{~m} / \mathrm{s}$ for wind speed. The seawater is assumed to have a temperature of $15{ }^{\circ} \mathrm{C}$, with a salt concentration of $35 \mathrm{~g} / \mathrm{kg}$. Table A1 presents specifications for the Dish-Stirling used in this study, while Table A2 shows the parameter specifications used in this study for PTSC. Table A3 displays the assumed parameter specifications for the DCMD used in this study. Table A4 illustrates the main parameters for the RSOFC component. Finally, in Table A5, the main parameters for the other components are listed.

\section{Results and discussions}

Simulations and main calculations were carried out using dynamic network analysis (DNA), which is an in-house software for energy systems analysis developed at the DTU Thermal Energy Section. DNA solves a system of non-linear equations through the Newton-Raphson modified algorithm, see, for example, [38]. The models were verified against the literature to assure quality of the results, but the verification is not reported here owing to limited space. In the sections that follow, the performance of each component is presented along with discussions of some of the interesting aspects of the components' performances.

\subsection{Dish-Stirling}

Figure 7 presents the power produced by a single Dish-Stirling unit. The power output depends directly on the solar irradiation, and has a maximum value of $24 \mathrm{~kW}$ at $1000 \mathrm{~W} / \mathrm{m}^{2}$. For 175 units, this maximum value corresponds to approximately 4.2 MW. However, the efficiency of the DishStirling is not proportional to the irradiation, as illustrated in Fig. 7. Its efficiency increases from approximately $22 \%$ at low irradiation (approximately $150 \mathrm{~W} / \mathrm{m}^{2}$ ) to approximately $26 \%$ at about 370 $\mathrm{W} / \mathrm{m}^{2}$. Afterwards, the increase in efficiency is not very severe. The efficiency increases to approximately $27 \%$ at about $700 \mathrm{~W} / \mathrm{m}^{2}$ and remains nearly constant until about $930 \mathrm{~W} / \mathrm{m}^{2}$.

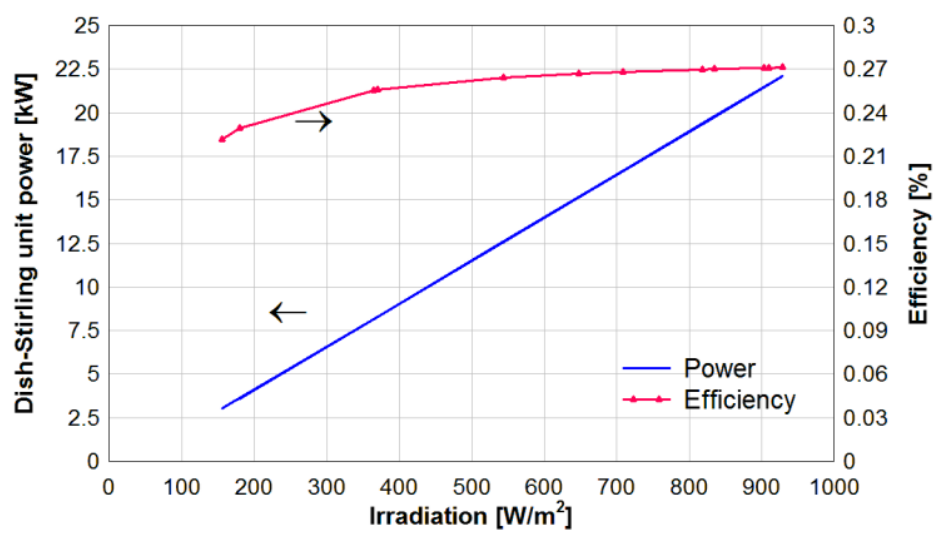

Figure 7. Dish-Stirling unit performance. Power (blue) and efficiency (red) as function of radiation. 


\subsection{PTSC}

Figure 8 shows the performance of the PTSC steam generator. As shown in the figure, the performance of the generator is proportional to the irradiation, as the inlet pressure and the outlet temperature are fixed regardless of the quantity of radiation. Therefore, the only variation will occur in the mass flow through the component. Accordingly, the temperature profile along the pipe is almost constant, with a saturation temperature of approximately $165^{\circ} \mathrm{C} \mathrm{[39];} \mathrm{thus,} \mathrm{the} \mathrm{heat} \mathrm{losses} \mathrm{to} \mathrm{the}$ environment remain constant. The small differences will be the consequence of higher pressure drops when the mass flow increases with higher solar irradiations.

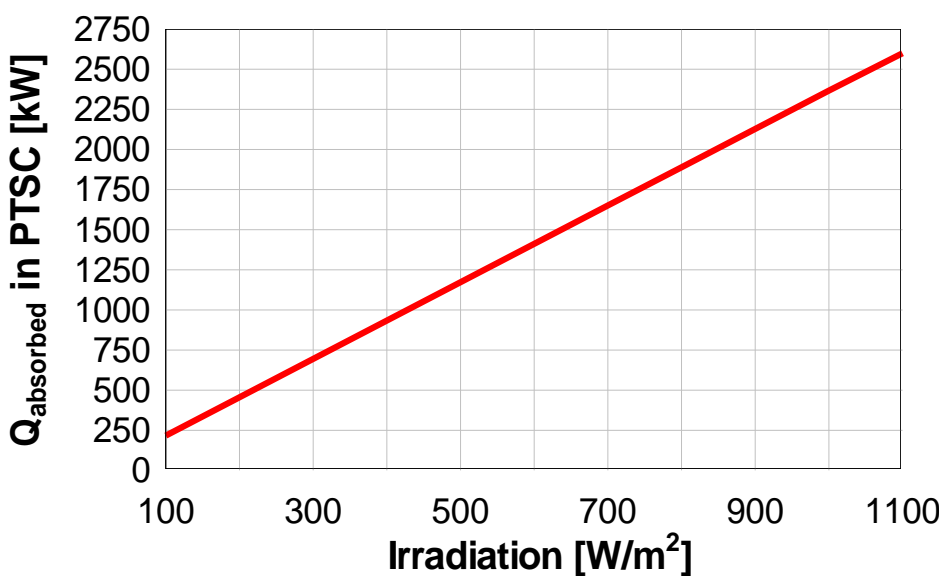

Figure 8. Performance of the PTSC steam generator.

\subsection{SOFC mode and SOFC system only}

The first parameter to be studied is the utilization factor $\left(U_{F}\right)$ of the SOFC mode. The higher this value is, the higher the power from the stack will be. However, when the SOFC is combined with another plant, such as a see-water desalination plant, as done in this study, the heat available for the other plant should also be considered when examining the plant's entire efficiency. The reason is that, by increasing the SOFC utilization factor, less off-fuel will be available for heating the bottoming cycle. As displayed in Fig. 6, the off- fuel (containing unburnt $\mathrm{H}_{2}$ ) will be sent to the condenser to separate the unreacted $\mathrm{H}_{2}$ from the off-fuel, and then sent back to the fuel storage tank (recovering the unused hydrogen). In traditional plant designs, a burner (catalytic burner) combusts the unreacted fuel to provide heat for the bottoming cycle, which is not the same case here. Thus, the efficiency of the SOFC plant can be described as

$$
\eta_{\text {el_SOFC }}^{*}=\frac{\text { POWER }}{L H V \cdot \dot{m}_{H 2, \text { consumed }} \cdot U_{F}}
$$

where $\dot{m}_{H 2, \text { consumed }}$ is the fuel consumed by the fuel cell stacks. Using such a definition, one can then study the effect of the utilization factor $\left(U_{F}\right)$ on SOFC plant efficiency. First, the fuel feed into the plant is assumed to be constant, which means that the fuel consumed in the fuel cell stacks changes accordingly. Figure 9 presents the results for this case. Note that in this case, the focus is on the SOFC plant only, and the freshwater system is not accounted for in the figure. The figure reveals that there exists an optimum $U_{F}$, for which the plant efficiency is a maximum. The plant efficiency reaches approximately $39 \%$ at a utilization factor of approximately $78 \%$. The sudden decrease in plant efficiency after this point is due to high concentration losses in the cells. It is also apparent that the plant roundtrip efficiency decreases from approximately $65 \%$ at $U_{F}=0.4$ to approximately $50 \%$ when $U_{F}=0.5$. When the system is operating at roundtrip efficiency, the unreacted hydrogen is recovered; hence, the plant's efficiency is significantly higher than in the traditional case, where a burner combusts the unreacted fuel. The assumption that $U_{F}=0.7$ made at the beginning is thus very close 
to the optimal value.

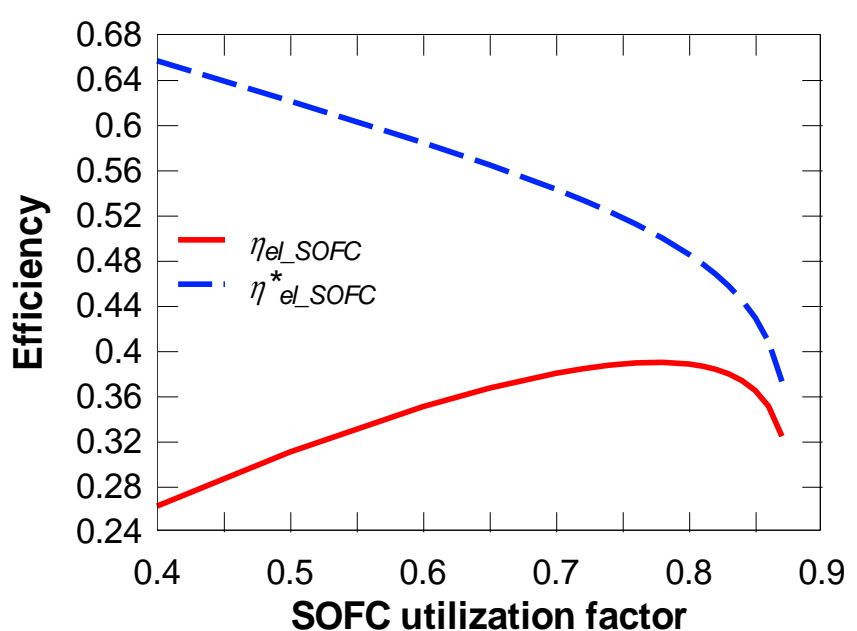

Figure 9. SOFC plant performance as function of utilization factor (when feeding fuel in constant).

Second, the fuel consumed by the stack is assumed to be constant, which means that the fuel fed into the plant changes accordingly. Equation (4) shows that under constant fuel consumption in the fuel cells, plant electrical efficiency increases by decreasing the fuel cell utilization factor. Table 1 shows that decreasing the utilization factor increases net-power production at the expense of heat production. Although fuel fed into the system increases to maintain the quantity of consumed fuel (by the fuel cells), when the utilization factor decreases, the air flow on the other side of the fuel cells decreases, as less heat needs to be removed from the SOFC (less power consumption in the air blower).

Table 1. SOFC mode cogeneration data with different utilization factors under constant fuel consumption in the fuel cells.

\begin{tabular}{l|r|r|r|r|r}
\hline $\boldsymbol{U}_{\boldsymbol{F}}$ & 0.8 & 0.7 & 0.6 & 0.5 & 0.4 \\
\hline Feeding fuel into the plant [kg/s] & 0.00875 & 0.01 & 0.01167 & 0.014 & 0.0175 \\
Fuel consumed by the fuel cells [kg/s] & 0.007 & 0.007 & 0.007 & 0.007 & 0.007 \\
Power [kW] & 404 & 445 & 474 & 499 & 523 \\
Heat* [kW] & 428 & 386 & 358 & 333 & 304 \\
Power share & $49 \%$ & $54 \%$ & $57 \%$ & $60 \%$ & $63 \%$ \\
Heating share & $51 \%$ & $46 \%$ & $43 \%$ & $40 \%$ & $37 \%$ \\
\hline
\end{tabular}

Heat* is accounting for the heat carried out by the RSOFC outlets that could potentially be used for seawater heating. At the end, not all of it is used because a certain quantity is wasted, mostly in the condenser.

Thus, one can manage the energy flows and consequently increase the roundtrip efficiency of the storage subsystem (including hydrogen production and storage). Such results are interesting, as they show, for example, how to run the system when freshwater consumption is low. For example, the heating share, which is used for freshwater production, decreases from $51 \%$ to $37 \%$ when the utilization factor decreases from 0.8 to 0.4 (although it is not clear if $U_{F}$ can be changed freely).

As mentioned previously, the utilization factor is assumed to be constant and equal to 0.7 for the base case. Table 2 shows the power produced by the system for different fuel mass flows that are fed into the plant and the comparison between both interpretations of the efficiencies used in this study (when hydrogen production is also accounted for). Note that the "Efficiency* ( $\eta^{*}$ el_SOFC)" better represents the performance of the system presented here, as it recovers the hydrogen that is not used in the fuel cells and sent back to the storage tank for future use. Equation (1) defines $\eta_{\text {el_sOFC }}$, while Eq. (54) defines $\eta^{*}$ el_SOFC. As shown, the roundtrip efficiency of the presented plant is very high and reaches approximately $57 \%$ when power production is about $259 \mathrm{~kW}$. However, the roundtrip 
551

552

553

554

555

556

557

558

559

560

561

562

563

564

565

566

567

568

569

570

571

572

573

574

575

576

577

578

579

580

581

efficiency decreases when the fuel fed to the plant increases to produce more power.

Table 2. SOFC mode power performance and efficiency summary.

\begin{tabular}{c|c|c|c|c}
\hline $\begin{array}{c}\text { Plant feeding fuel } \\
{[\mathbf{k g} / \mathbf{s}]}\end{array}$ & $\begin{array}{c}\text { Fuel consumed in the fuel } \\
\text { cells }[\mathbf{k g} / \mathbf{s}]\end{array}$ & $\begin{array}{c}\text { Total power } \\
{[\mathbf{k W}]}\end{array}$ & $\begin{array}{c}\text { Efficiency } \\
\left(\eta_{e l_{-} S O F C}\right)\end{array}$ & $\begin{array}{c}\text { Efficiency* } \\
\left(\eta_{\text {el_SOFC }}^{*}\right)\end{array}$ \\
\hline 0.005 & 0.0035 & 259 & $40 \%$ & $57 \%$ \\
0.01 & 0.007 & 494 & $37 \%$ & $54 \%$ \\
0.015 & 0.0105 & 703 & $35 \%$ & $51 \%$ \\
0.02 & 0.014 & 887 & $33 \%$ & $47 \%$ \\
0.024 & 0.0168 & 990 & $31 \%$ & $44 \%$ \\
\hline
\end{tabular}

\subsection{SOEC mode and SOEC system only}

Table 3 presents the performance summary of the plant in the SOEC mode in which the inlet and outlet temperatures, and pressure of the steam remain constant. Interestingly, the cell voltage increases with the steam inlet mass flow. This occurs because the power input must increase to generate more heat, which increases the inlet temperatures up to the operation temperature $\left(750^{\circ} \mathrm{C}\right)$, and energy balance is finally achieved. In fact, if the inlet temperature was set to $750^{\circ} \mathrm{C}$, the thermoneutral cell voltage would be approximately $1.285 \mathrm{~V}$, and it would remain constant. In the literature, other authors have used a burner to transfer the necessarily additional heat to the steam, but in this study, the idea is to run the plant with only solar energy.

Table 3. SOEC mode performance summary (4 bar).

\begin{tabular}{c|c|c|c|c|c}
\hline $\begin{array}{c}\mathbf{H}_{2} \mathrm{O} \text { in } \\
{[\mathbf{k g} / \mathbf{s}]}\end{array}$ & $\begin{array}{c}\text { Power Consumed } \\
\text { by SOECs }[\mathbf{k W}]\end{array}$ & $\begin{array}{c}\text { Efficiency } \\
{[\%]}\end{array}$ & $\begin{array}{c}\mathbf{H} 2 \text { Produced } \\
{[\mathbf{k g} / \mathbf{s}]}\end{array}$ & $\begin{array}{c}\text { Current density } \\
\left(\mathbf{m A} / \mathbf{c m}^{2}\right)\end{array}$ & $\begin{array}{c}\boldsymbol{E}_{\text {cell }} \\
{[\mathbf{V}]}\end{array}$ \\
\hline 0.05756 & 731.50 & $75.3 \%$ & 0.005797 & 275.2 & 1.318 \\
0.09023 & 1021.0 & $73.4 \%$ & 0.008078 & 383.6 & 1.320 \\
0.12949 & 1284.7 & $71.1 \%$ & 0.010144 & 481.6 & 1.323 \\
0.18323 & 1562.5 & $68.3 \%$ & 0.012303 & 584.1 & 1.327 \\
0.26363 & 1880.7 & $64.7 \%$ & 0.014751 & 700.4 & 1.332 \\
0.39642 & 2275.3 & $59.9 \%$ & 0.017744 & 842.5 & 1.340 \\
0.64894 & 2820.2 & $53.4 \%$ & 0.021786 & 1034.4 & 1.352 \\
\hline
\end{tabular}

As revealed in Table 3, the SOEC plant efficiency (without fresh water production) reaches values of more than $75 \%$ at low $\mathrm{H}_{2}$ production rate and decreases when $\mathrm{H}_{2}$ production increases. Equation (10) defines the SOEC plant efficiency presented in Table 3. However, it also would be interesting to determine the electrolysis efficiency without considering the heat required to preheat the incoming water that feeds the cells (as shown by studies in the literature). Thus, the efficiency is defined as

$$
\eta_{S O E C}^{*}=\frac{L H V \cdot \dot{m}_{H 2, \text { produced }}}{\text { POWER }}
$$

It is worth noting that the mass flow required to calculate $Q_{i n}$ in Eq. (10) is the water mass flow entering the SOEC only (point 4 in Figure 5). However, the PTSC preheats additional water that is used to preheat the seawater (point 11 in Figure 5) and the mass flow for this one is much higher than the one used in SOEC. Therefore, one may define a combined SOEC-DCMD efficiency as

$$
\eta_{S O E C-D C M D}=\frac{L H V \cdot \dot{m}_{H 2, \text { produced }}}{P O W E R+Q_{P T S C}}
$$

where $Q_{P T S C}$ is the total heat produced by the parabolic trough solar collector. Figure 10 shows the results of such efficiency calculations as functions of hydrogen production (in kilograms per hour). 
As presented, the efficiency of the SOEC stacks only (without accounting for water preheating) remains very high at approximately $91 \%-93 \%$, while the SOEC plant efficiency (including water preheating) decreases from approximately $75 \%$ at low $\mathrm{H}_{2}$ production to approximately $54 \%$ at high $\mathrm{H}_{2}$ production. However, the plant efficiency (SOEC with DCMD) increases from approximately $20 \%$ at low $\mathrm{H}_{2}$ production to approximately $47 \%$ at high $\mathrm{H}_{2}$ production.

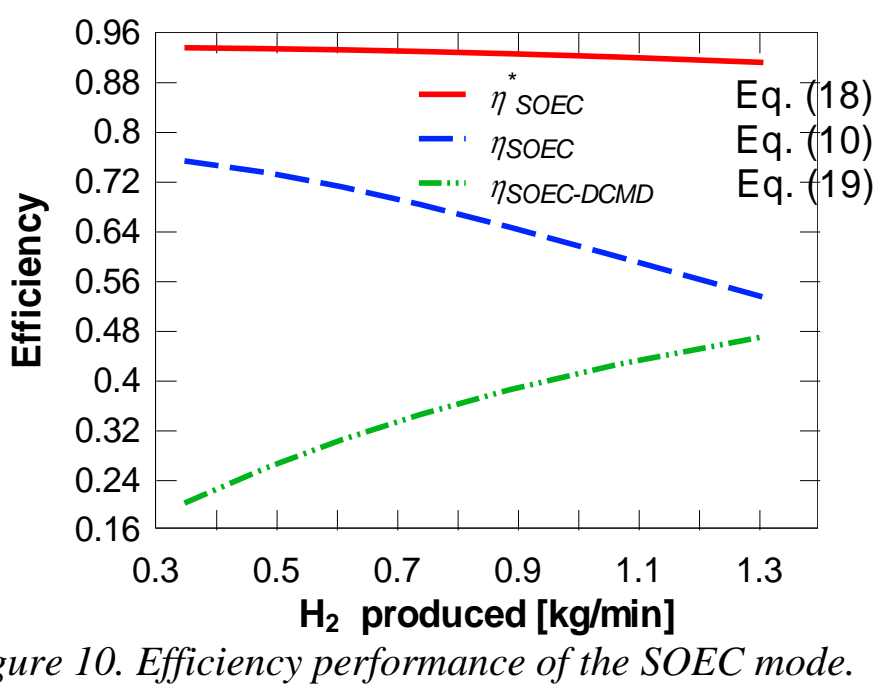

Another interesting result that can be extracted from Table 1 and Table 3 is the approximate value of the roundtrip efficiency of the storage system. Knowing the dual-mode efficiency allows one to infer the approximate cost of storing energy, or in other words, how much of the power input can be used again. This value varies depending on the operation range, but its mean is approximately $42-$ $45 \%$ when only the electrical output is considered. In practice, there is a higher utilization of that energy, as the heat released during the storing cycle can be used for freshwater production.

One of the challenges for such system is the plant price and payback time. The prices for RSOC and DCMD are unknown since they are not commercialized yet. Even though there is a good price approximation for each of them but still they cannot be certain. Political decisions and governmental subsidies will also have a great impact on future price development of such devices [40]. All these are out the scope of this study and will not be discussed here.

\subsection{Case study - dual mode}

To show the performance of the entire system (both SOEC and SOFC modes), real solar irradiation data from a random day is used. In this study, the data used for investigation is for a random day in South Africa [41]. The reason is that a detailed radiation, hour by hour, for an entire is presented/published. The system is evaluated and analyzed in terms of efficiency and productivity. The simulations are carried out with hourly data, and it is assumed that steady state is achieved within each hour. In order to concentrate on plant performance, the power demand during the day is set as $500 \mathrm{~kW}$. Thus, it is easier to compare the differences in terms of power demand and production profile. It is worth mentioning that fulfilling such a power demand (in $24 \mathrm{~h}$ ) is challenging for a solar plant owing to intermittency of the source. Currently, only a few solar plants can produce such power in $24 \mathrm{~h}$ using thermal storage.

In order to carry out the simulations, one needs to distinguish the demand power from the production power. Figure 11 presents the difference in the power demand and power production profiles over the course of an entire day $(24 \mathrm{~h})$. One can immediately notice that the power production is much higher than the power demand during daylight. This provides the basis for storing power and using it when demand is higher than production. The shift between the operations modes over the course of $24 \mathrm{~h}$ is designated as follows: 
- $\quad[06: 00-07: 00] \rightarrow$ SOFC MODE + STIRLING + PTSC

- $\quad[07: 00-18: 00] \rightarrow$ SOEC MODE + STIRLING + PTSC

- $\quad[18: 00-19: 00] \rightarrow$ SOFC MODE + STIRLING + PTSC

- [19:00 - 00:00] $\rightarrow$ SOFC MODE

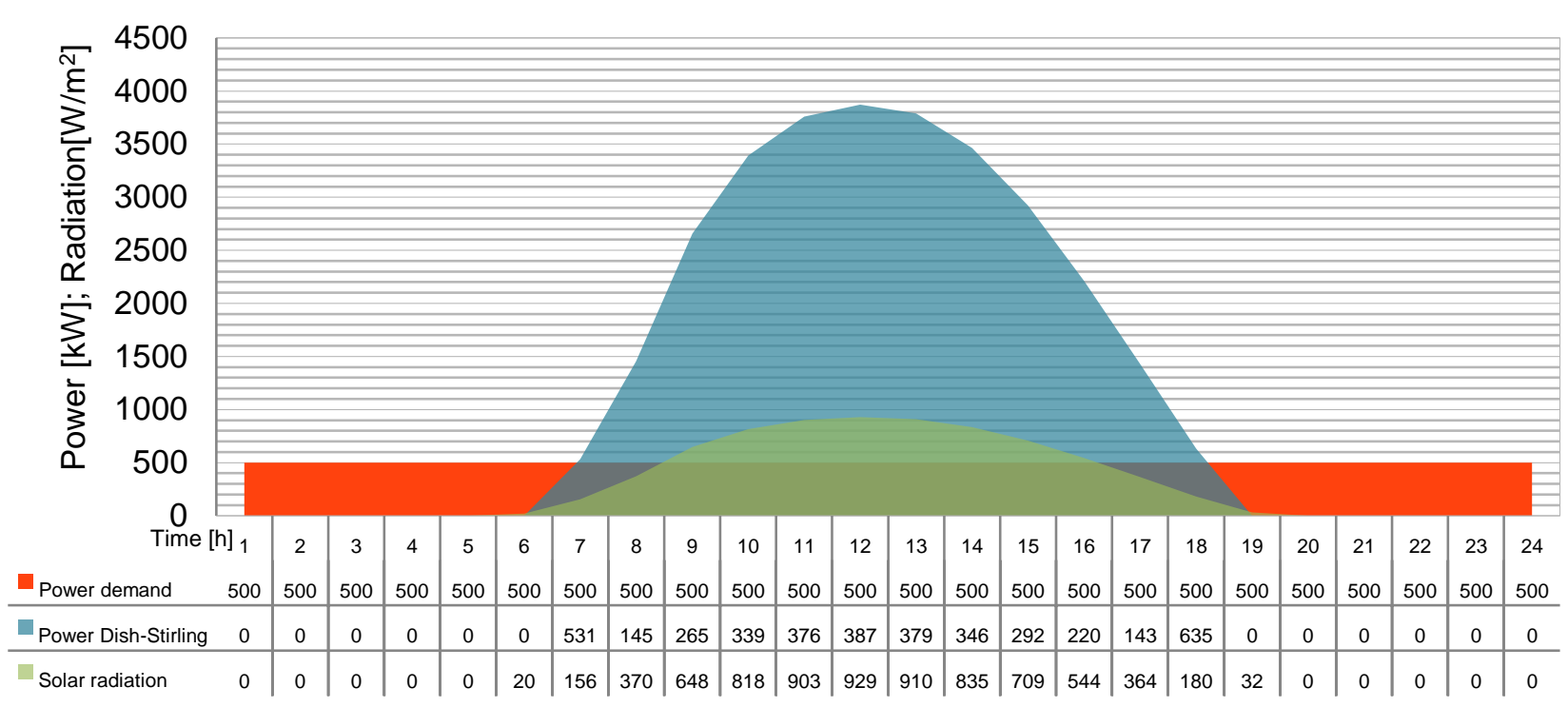

\section{Figure 11. One day hourly data for direct radiation $\left[\mathrm{W} / \mathrm{m}^{2}\right]$, power of Dish-Stirling [kW] and power demand $[k W]$.}

Figure 12 displays the results obtained from the RSOFC (dual mode) plant proposed in this study over $24 \mathrm{~h}$ (both SOEC and SOFC modes) in terms of freshwater and hydrogen production. During daytime, the plant produces power that satisfies the electrical power demand. At the same time, it stores energy in form of $\mathrm{H}_{2}$ (power to gas), and then uses this stored energy during the nighttime to produce power. The difference between consumption and production rates according to the operation mode within each time gap is distinguishable. Note that there is a positive net balance of $\mathrm{H}_{2}$, meaning that at the end of the day, there is approximately $295 \mathrm{~kg}$ or $3281 \mathrm{Sm}^{3}$ (standardized cubic meter, 15 ${ }^{\circ} \mathrm{C}$ and 1.01325 bar) more $\mathrm{H}_{2}$ in the tank than on the previous day. Such encouraging results should be taken into account when designing such plants (independent on external fuel). The chosen day seems to be appropriate in terms of solar radiation because it allows for the storage of excess fuel, which could be utilized on the following day. However, in an entire year, there will be some days with less irradiation (or none at all); therefore, it is important to increase the capacity of the stored fuel so that more fuel reserves are available when sun radiation is low. Further, the additional $295 \mathrm{~kg}$ of $\mathrm{H}_{2}$ that is stored allows the system to run for approximately $10 \mathrm{~h}$ without any irradiation from the sun (during nighttime). Of course, to study the amount of hydrogen for an entire year, one needs to simulate the system for all days of the year by knowing the expected irradiation for each day, which is an extensive undertaking that requires additional weather data for the specified location. 


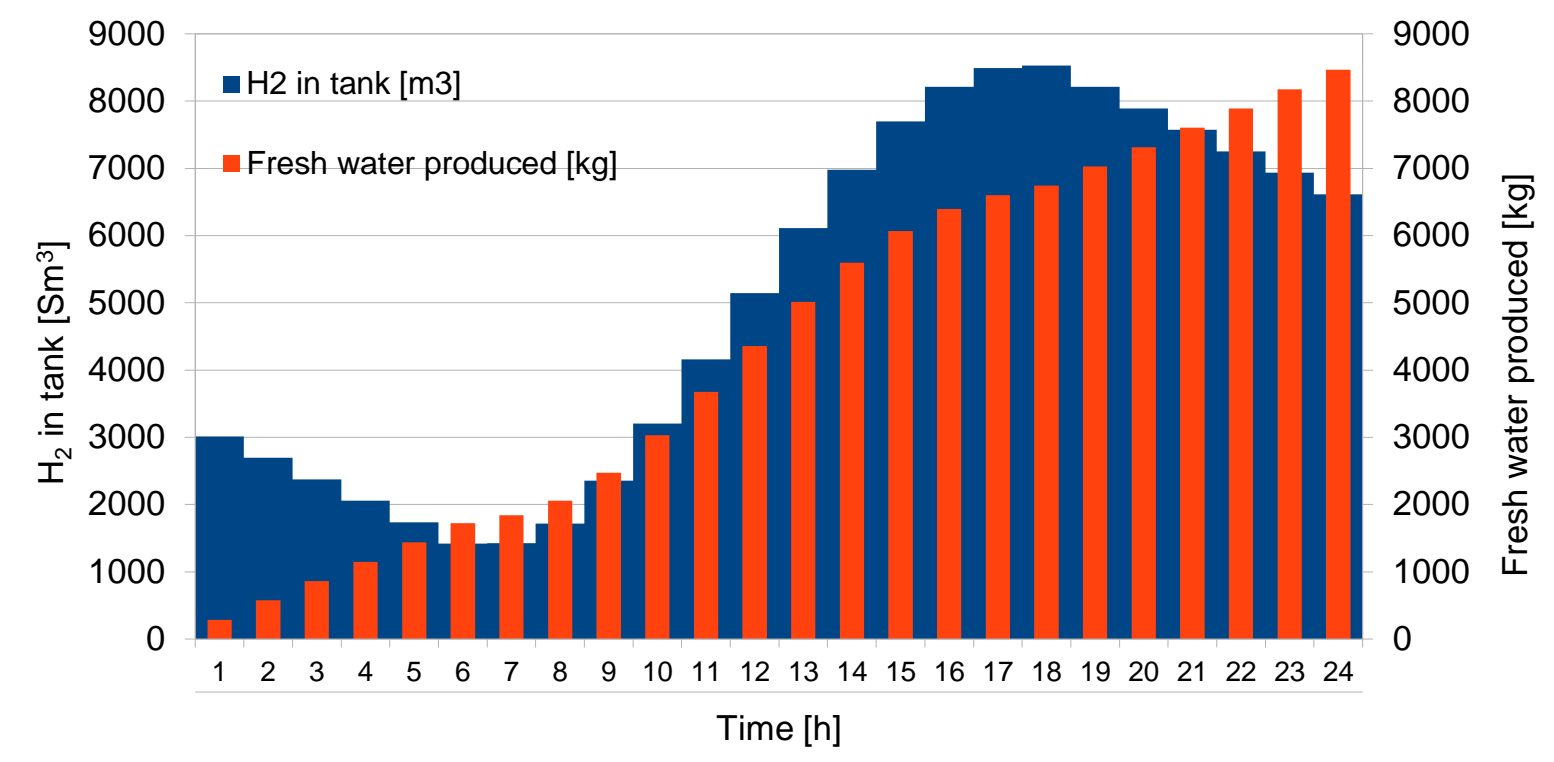

Figure 12: Hydrogen and fresh water stock variation along day

Conversely, the total amount of water distilled on that particular day is 8466 liters. As explained earlier, one can convert such quantities of water into an energy value (for sake of comparison) by taking into account the necessary energy needed to evaporate the seawater at $15^{\circ} \mathrm{C}$ (and at 1 atm) as the reference point. The result is $6094 \mathrm{kWh}$, as shown in Table 4. In order to obtain a performance indicator for the DCMD system, this number can then be compared to the total heat that is transferred to the seawater during that day. As shown in Table 4, the energy transfer to the DCMD is approximately 2.7 times larger than the energy received by the DCMD, meaning than the efficiency of the DCMD system is estimated to be approximately $37 \%$, which can be attributed to the high salt concentration in the seawater. On the other hand, the results indicate that there is a potential to increase the efficiency of the freshwater production maybe by other distillation systems. This could be possible because of the high temperature of the gases released by the RSOFC and the outlet temperature of the PTSC.

Table 4: Summary of the total energy flows on the specified day.

\begin{tabular}{lr}
\hline Total energy flow & \\
\hline Solar energy & $145065 \mathrm{kWh}$ \\
Freshwater energy (DCMD) & $6094 \mathrm{kWh}$ \\
Heat transferred to seawater & $16426 \mathrm{kWh}$ \\
Hydrogen energy & $9843 \mathrm{kWh}$ \\
Energy to grid & $12000 \mathrm{kWh}$ \\
\hline
\end{tabular}

Finally, from Table 4, it is also possible to calculate the overall efficiency of the system (as defined in Eq. (1)), which is approximately 19.3\%. Nevertheless, if one considers the actual energy transferred to the seawater (allowing use of other types of freshwater production systems) instead of the freshwater distilled by the DCMD, then the overall system efficiency increases to $26.4 \%$.

\section{Conclusions}

A novel system is proposed to deliver electricity and freshwater from sun radiation at any time (day and night), even though there is no irradiation for a short period. The presented system uses a reversible solid oxide cells technology, Dish-Stirling engines, parabolic trough solar collectors, and direct contact membrane distillations units.

The plant is evaluated on a random day in South Africa where it has to supply a constant demand 
of $500 \mathrm{~kW}, 24 \mathrm{~h}$ a day. The results indicate that, with a RSOFC of 70 stacks of 200 cells, 175 units of $25 \mathrm{~kW}$ Dish-Stirling and a $7 \times 200 \mathrm{~m}$ of PTSC, the plant was not only able to meet the constant demand but was also able to produce $3281 \mathrm{Sm}^{3}$ of $\mathrm{H}_{2}$ and 8466 liters of freshwater each day. This system reached an energy efficiency of $19.3 \%$, including electricity, hydrogen production and freshwater production. It is also found that there is a potential to produce much more freshwater than that produced by the current DCMD technology. If a re-configuration is applied, the system could reach an energy efficiency of $26.4 \%$, which is rather high for such applications.

\section{Nomenclature}

\begin{tabular}{|c|c|}
\hline A & Area, $\left[\mathrm{m}^{2}\right]$ \\
\hline $\mathrm{AC}$ & Alternate Current \\
\hline AP & Anode preheater \\
\hline $\mathrm{C}$ & Compressor \\
\hline $\mathrm{CP}$ & Cathode preheater \\
\hline$c_{p}$ & Heat capacity, $[\mathrm{J} /(\mathrm{kgK})]$ \\
\hline $\mathrm{C}_{\mathrm{R}}$ & Concentration ratio \\
\hline $\mathrm{D}, \mathrm{d}$ & Diameter, [m] \\
\hline DC & Direct Current \\
\hline DCMD & Direct Contact Membrane Distillation \\
\hline DNA & Dynamic Network Analysis \\
\hline $\mathrm{dp}$ & Relative pressure drops, [bar] \\
\hline$E$ & Voltage, [V] \\
\hline $\mathrm{EC}$ & Electrolyzer cell \\
\hline EES & Electrical Energy Storage \\
\hline$F$ & Faraday's constant : $96485.3365[\mathrm{C} / \mathrm{mol}]$ \\
\hline $\mathrm{FC}$ & Fuel Cell \\
\hline$f_{\text {loss }}$ & loss factor, $[-]$ \\
\hline$f_{s}$ & Friction coefficient, $[-]$ \\
\hline$G$ & Gibbs energy \\
\hline$g$ & Universal gravity constant $: 9.81\left[\mathrm{~m} / \mathrm{s}^{2}\right]$ \\
\hline$\dot{G}$ & Mass velocity, $\left[\mathrm{kg} /\left(\mathrm{sm}^{2}\right)\right]$ \\
\hline$H$, eth & Enthalpy, $[\mathrm{J}]$ \\
\hline$h$ & Convection coefficient, $\left[\mathrm{W} /\left(\mathrm{m}^{2} \mathrm{~K}\right)\right]$ \\
\hline HTF & Heat transfer fluid \\
\hline $\mathrm{HX}$ & Heat Exchanger \\
\hline $\mathrm{H} 2$ & Hydrogen \\
\hline$i$ & Current, $[\mathrm{A}]$ \\
\hline $\mathrm{J}$ & Current density, $\left[\mathrm{A} / \mathrm{m}^{2}\right]$ \\
\hline $\mathrm{k}$ & Conductivity, $[\mathrm{W} /(\mathrm{mK})]$ \\
\hline$K_{\gamma \tau \alpha}$ & Incidence angle modifier, $[-]$ \\
\hline $\mathrm{L}, 1$ & Length, [m] \\
\hline LEP & Liquid Entry Pressure [bar] \\
\hline LHV & Low heating value, $[\mathrm{J}]$ \\
\hline M & Molar mass \\
\hline MD & Membrane Distillation \\
\hline$\dot{m}$ & Mass flow, $[\mathrm{kg} / \mathrm{s}]$ \\
\hline $\mathrm{N}_{\text {cell }}$ & Number of cells per stack \\
\hline $\mathrm{N}_{\text {stack }}$ & Number of Stacks \\
\hline$\dot{N}$ & Molar flow \\
\hline $\mathrm{P}$ & Power, [W] \\
\hline $\mathrm{p}$ & Pressure, [bar] \\
\hline
\end{tabular}




$\begin{array}{ll}\mathrm{p}^{0} & \text { Partial pressure } \\ \text { PF } & \text { Feed pressure, [bar] } \\ \text { PFm } & \text { Membrane pressure on the feed side, [bar] } \\ \text { PP } & \text { Permeate pressure, [bar] } \\ \text { PPm } & \text { Membrane pressure on the permeate side, [bar] } \\ \text { Pr } & \text { Prandtl number [-] } \\ \text { PTSC } & \text { Parabolic Trough Solar Collector } \\ \text { PTSC-SG } & \text { Parabolic Trough Solar Collector Steam Generator } \\ \text { PV } & \text { Photovoltaic } \\ \text { Q } & \text { Heat, [J/s] } \\ \text { R } & \text { Universal gas constant: } 8.314[\mathrm{~J} /(\mathrm{mol} . \mathrm{K})] \\ \text { Re } & \text { Reynold's number, [-] } \\ \text { RSOFC } & \text { Reversible Solid Oxide Fuel Cell } \\ \text { RSOC } & \text { Reversible Solid Oxide Cell } \\ \text { S } & \left.\text { Direct sun radiation, [W/m }{ }^{2}\right] \\ \text { S } & \text { Section } \\ \text { SOEC } & \text { Solid Oxide Electrolyze Cell } \\ \text { SOFC } & \text { Solid Oxide Fuel Cell } \\ \text { SWP } & \text { Sea water preheater } \\ \text { t } & \text { Thickness, [m] } \\ \text { T } & \text { Temperature, }[\mathrm{K}] \\ \mathrm{U} & \left.\left.\text { Heat transfer coefficient, [W/(m }{ }^{2} \mathrm{~K}\right)\right] \\ \mathrm{U}_{\mathrm{cc}} & \text { Combined heat loss transfer coefficient, }\left[\mathrm{W} /\left(\mathrm{m}^{2} \mathrm{~K}\right)\right] \\ U_{F} & \text { Utilization Factor, }[-] \\ x & \text { Vapor quality, }[-] \\ \mathrm{v} & \text { Velocity [m/s], specific volume }\left[\mathrm{m}^{3}\right] \\ \mathrm{w} & \text { Aperture } \\ & \end{array}$

\section{$\underline{\text { Greek letters }}$}

\begin{tabular}{ll}
\hline$\Delta$ & Difference \\
$\Upsilon$ & Heat capacity ratio \\
$\Omega$ & Molecular diameter of air \\
$\alpha$ & Absorptance \\
$\delta$ & Absolute roughness \\
$\varepsilon$ & Porosity \\
$\epsilon$ & Emissivity \\
$\phi$ & Angle of incidence \\
$\gamma$ & Intercept factor, $[-]$ \\
$\eta$ & Efficiency, $[-]$ \\
$\varphi$ & Specular reflectance \\
$\lambda$ & Mean free path \\
$\mu$ & Dynamic viscosity, $\left[\mathrm{m}^{2} / \mathrm{s}\right]$ \\
$\pi$ & Pi : 3.1416 \\
$\rho$ & Density, [kg/m $\left.{ }^{3}\right]$ \\
$\sigma$ & Stefan-Boltzmann constant : $5.678 \times 10^{-8} \mathrm{~W} / \mathrm{m}^{2} \mathrm{~K}^{4}$ \\
$\tau$ & Transmittance, $[-]$ \\
$\xi$ & Compression ratio, $[-]$ \\
$\psi$ & Surface tension \\
$\zeta$ & Gas temperature ratio, $[-]$
\end{tabular}

$\underline{\text { Subscripts }}$ 


\begin{tabular}{|c|c|}
\hline absf & Absorbed by the fluid \\
\hline act & Activation \\
\hline $\mathrm{amb}$ & Ambient \\
\hline an & Anode \\
\hline as & Anode limit \\
\hline cath & Cathode \\
\hline ci & Inner part of the cover \\
\hline co & Outer part of the cover \\
\hline conc & Concentration \\
\hline $\operatorname{cov}$ & Cover \\
\hline cs & Cathode limit \\
\hline dens & Density \\
\hline eff & Effective \\
\hline el & Electrolyte \\
\hline $\mathrm{f}$ & Feed side \\
\hline $\mathrm{fm}$ & Fluid mean \\
\hline $\mathrm{G}$ & Gas \\
\hline gen & Generator \\
\hline in & Inlet \\
\hline $\mathrm{L}$ & Liquid, Loss \\
\hline $\mathrm{m}$ & Membrane \\
\hline ohm & Ohmic \\
\hline opt & Optimal \\
\hline out & Outlet \\
\hline $\mathrm{p}$ & Permeate side \\
\hline $\mathrm{r}$ & Reaction \\
\hline rec & Receiver \\
\hline ri & Inner part of the receiver \\
\hline ro & Outer part of the receiver \\
\hline ROM & Receiver Out (surface) Mean \\
\hline s & Isentropic \\
\hline supp & Support \\
\hline thn & Thermoneutral \\
\hline w & Wind \\
\hline $\mathrm{z}$ & Segment number \\
\hline
\end{tabular}

\section{References}

1. Ni M, Leung MKH, Leung DYC. Technological development of hydrogen production by solid oxide electrolyzer cell (SOEC). Hydrogen Energy 2008:33;2337-54.

2. Abuadala A, Dincer I. Exergoeconomic analysis of a hybrid system based on steam biomass gasification products for hydrogen production. Hydrogen Energy 2011:36;12780-93.

3. Viviani M, Canu G, Carpanese MP, Barbucci A, et al. Dual cells with mixed protonic-anionic conductivity for reversible SOFC/SOEC operation. Energy Procedia 2012:182-189.

4. Dillig M, Leimert J, Karl J. Planar High Temperature Heat Pipes for SOFC/SOEC Stack Applications. Fuel Cells 2014:14;479-488.

5. Odeh SD and Morrison GL. Optimization of parabolic trough solar collector system. Int J Energy Research 2006:30;259-271. 
6. Coccia G, Latini G, Sotte M. Mathematical modeling of a prototype of parabolic through solar collector. Renewable and Sustainable Energy 2012:4 (023110):1-15.

7. Li C, Wang RZ, Wang LW, Li TX, Chen Y. Experimental study on an adsorption icemaker driven by parabolic trough solar collector. Renewable Energy 2012:57;223-233.

8. Bortolato M, Dugaria S, Del Col D. Experimental study of a parabolic trough solar collector with flat bar-and-plate absorber during direct steam generation. Energy 2016:116;1039-50.

9. Burgoyne A, Vahdati MM. Direct Contact Membrane Distillation. Desalination and Water Treatment 2000:35(8);1257-84.

10. Shirazi MMA, Kargari A, Shirazi MJA. Direct contact membrane distillation for seawater desalination. Separation Science and Technology 2012:49;368-375.

11. Suárez F, Ruskowitz JA, Tyler SW, Childress AE. Renewable water: Direct contact membrane distillation coupled with solar ponds. Applied Energy 2015:158;532-539.

12. Nakoa K, Date A, Akbarzadeh A. DCMD modelling and experimental study using PTFE membrane. Desalination and Water Treatment 2016:57;3835-45.

13. Cath TY, Adams VD, Childress AE. Experimental study of desalination using direct contact membrane distillation: a new approach to flux enhancement. Membrane Science 2003:228;5-16.

14. Akikur RK, Saidur R, Ping HW, Ullah KR. Performance analysis of a co-generation system using solar energy and SOFC technology. Energy Conversion and Management 2014:79;415-430.

15. Garc1'a-Valverde, Espinosa N, Urbina A. Optimized method for photovoltaic-water electrolyser direct coupling. Hydrogen Energy 2011:36;10574-86.

16. Ghribi D, Khelifa A, Diaf S, Belhamel M. Study of hydrogen production system by using PV solar energy and PEM electrolyser in Algeria. Hydrogen Energy 2013:38;8480-90.

17. Monnerie N, von Storch H, Houaijia A, Roeb M, Sattler C. Hydrogen production by coupling pressurized high temperature electrolyser with solar tower technology. Hydrogen Energy 2017:42;13498-509.

18. Rokni M. Thermodynamic analysis of an integrated solid oxide fuel cell cycle. Energy Conversion and Management 2010:51;2724-2732.

19. Rokni M. Thermodynamic analyses of municipal solid waste gasification plant integrated with solid oxide fuel cell and Stirling hybrid system. Hydrogen Energy 2015:40;7855-7869.

20. Ni M, Leung KH, Leung DYC. Energy and exergy analysis of hydrogen production by solid oxide steam electrolyzer plant. Hydrogen Energy 2007:32; 4648-4660.

21. Ni M, Leung KH, Leung DYC. A modeling study on concentration overpotentials of a reversible solid oxide fuel cell. Power Sources 2006:163;460-466.

22. Hernández-Pacheco E, Singh D, Nutton PN, Patel N, Mann MD. A macro-level model for determining the performance characteristics of solid oxide fuel cells. Power Sources 2004:138;174-186.

23. Duffie JA and Beckman WA. Solar Engineering of Thermal Processes. $4^{\text {th }}$ Ed., John Wiley\& Sons, 2013, ISBN 978-1-118-41541-2 (ebk).

24. Rokni M. Thermodynamic analysis of SOFC (solid oxide fuel cell)-Stirling hybrid plants using alternative fuels. Energy 2013:61;87-97.

25. Reader GT. The pseudo Stirling cycle - a suitable performance criterion. Proceeding of the 13th intersociety energy conversion engineering conference 1979; 3:1763-770, San Diego, California, August 20-25.

26. Stine WB and Diver RB. A Compendium of solar dish/Stirling technology. 1994. Available form US DOE under contract Nr. 67-3678, Report Nr. SAND93-7026 UC-236.

27. Odeh SD, Morrison GL and Behnia M. Modeling of parabolic trough direct steam generation solar collectors. Solar Energy 1998:62;395-406. 
28. Gungor KE, Winteron RHS. A general correlation for flow boiling in tubes and annuli. Int. J. Heat Mass Transfer 1986:29(3);351-358.

29. Hammad M, Al-Qtiemat A, and Alshqirate A. Modeling and Analysis of the Performance of a Parabolic Trough Solar Concentrator System. ASME International Mechanical Engineering Congress and Exposition, IMECE 2013-63411, Nov. 15-21, San Diego, USA 2013. DOI 10.1115/IMECE2013-63411.

30. Thome JR. Two-Phase pressure drops inside tubes. in Databook III. Laboratory of Heat and Mass Transfer, Swiss Federal Institute of Technology Lausanne, Switzerland. http://ltcm.epfl.ch

31. Incropera FP, DeWitt DP, Bergman TL and Lavine AS. Introduction to Heat Transfer. 5th ed, Wiley 2006, ISBN 978-0471457275.

32. Nellis G, Klein S. Heat Transfer. Cambridge 2009, ISBN 978-0-521-88107-4.

33. Rohsenow WM, Hartnett JP, Cho YI. Handbook of heat transfer, 3rd ed. McGraw-Hill 1998. ISBN 0-07-053555-8.

34. Poling BE, Prausnitz JM and O'Connell JP. The Properties of Gases and Liquids.: $5^{\text {th }}$ Ed., McGraw-Hill, 2004, Digital version available.

35. Kim YD, Thu K, Ghaffour N, Ng KC. Performance investigation of a solar-assisted direct contact membrane. Membrane Science 2013:427345-364.

36. AlZahrani AA and Dincer I. Thermodynamic and electrochemical analyses of a solid oxide electrolyzer for hydrogen production. Hydrogen Energy 2017:21404-23.

37. Jensen SH, Sun X, Ebbesen SD, Knibbe R, Mogensen M. Hydrogen and synthetic fuel production using pressurized solid oxide electrolysis cells. Hydrogen Energy 2010:9544-49.

38. Elmegaard B. Simulation of Boiler Dynamics - development, evaluation and application of a general energy system simulation tool. PhD. Thesis 1999, Technical University of Denmark, Report Nr: ET-PhD 99-02. ISBN 87-7475-222-7.

39. Engineering Toolbox. [Online]. www.engineeringtoolbox.com Assessed April 2017.

40. Schmidt O, Gambhir A, Staffell I, Hawkes A, Nelson J, Few S. Future cost and performance of water electrolysis: An expert elicitation study. Hydrogen Energy 2017:42;30470-92.

41. Ciolkosz D. SASRAD: An hourly-timestep solar radiation database for South Africa. J. Energy in Southern Africa 2009:20(1);25-34. 
Table A2. PTSC main specifications

\begin{tabular}{ll}
\hline PTSC & \\
\hline Length & $250 \mathrm{~m}$ \\
Number of rows & 7 \\
Number of units $\left(N_{\text {unit }}\right)$ & 175 \\
Receiver & $33,38 \mathrm{~mm}$ \\
\hline Diameters $\left(D_{r i}, D_{r o}\right)$ & Stainless steel \\
Material & $60 \mathrm{~W} / \mathrm{mK}$ \\
Conductivity $\left(k_{r}\right)$ & Black Niquel \\
Coating & 0.06 \\
Emissivity $\left(\varepsilon_{r}\right)$ & 0.94 \\
Absorptivity $(\alpha)$ & \\
Cover & $84,90 \mathrm{~mm}$ \\
Diameters $\left(D_{c i}, D_{c o}\right)$ & Glass \\
Material & $0.035 \mathrm{~W} / \mathrm{mK}$ \\
Conductivity $\left(k_{c}\right)$ & 0.84 \\
Emissivity $\left(\varepsilon_{c}\right)$ & 0.94 \\
Transmissivity $(\tau)$ & $0.5 \mathrm{mbar}$ \\
Air pressure in the gap $\left(p_{m}\right)$ & \\
Concentrator & 0.93 \\
Reflectivity $(\varphi)$ & 0.93 \\
Intercept factor $(\gamma)$ & $2.5 \mathrm{~m}$ \\
Aperture & 1 \\
Incidence angle modifier $(\beta)$ & $20 \%$ of the heat to ambient \\
Manifold losses & 156 \\
Other Information & $28^{\circ} \mathrm{C}$ \\
Irradiation, $S\left[\mathrm{~W} / \mathrm{m}^{2}\right]$ & $20^{\circ} \mathrm{C}$ \\
Ambient temperature $\left(T_{a m b}\right)$ & $5 \mathrm{~m} / \mathrm{s}$ \\
Sky temperature $\left(T_{s k y}\right)$ & $80^{\circ} \mathrm{C}$ \\
Wind velocity $\left(V_{\text {wind }}\right)$ & \\
Saturation temperature $\left(T_{s a t}\right)$ & \\
\hline
\end{tabular}

Table A3. DCMD hollow fiber module specifications.

\begin{tabular}{ll}
\hline DCMD Hollow Fiber Module & \\
\hline Fiber length & $0.4 \mathrm{~m}$ \\
Inner diameter of fiber & $0.3 \mathrm{~mm}$ \\
Membrane thickness & $60 \mu \mathrm{m}$ \\
Porosity & $75 \%$ \\
Membrane conductivity & $0.25 \mathrm{~W} / \mathrm{mK}$ \\
Shell diameter & $0.003 \mathrm{~m}$ \\
Number of fibers & 3000 \\
Packing density & $60 \%$ \\
Model Constants & \\
\multicolumn{1}{c}{$C_{k}$} & $15.18 \times 10^{-4}$ \\
$C_{m}$ & $5.1 \times 10^{3} \mathrm{~m}^{-1}$ \\
$C_{p}$ & $12.97 \times 10^{-11} \mathrm{~m}$ \\
\hline
\end{tabular}


Table A4. RSOFC specification (anode and cathode referred to fuel cell mode).

\begin{tabular}{ll}
\hline RSOFC & \\
\hline Anode thickness & $600 \mu \mathrm{m}$ (Nickel and Yttria Stabilized Zirconia cermet) \\
Cathode thickness & $50 \mu \mathrm{m}$ (Strontium-doped lanthanum manganite) \\
Electrolyte thickness & $10 \mu \mathrm{m}$ (Yttria Stabilized Zirconia) \\
Cell area & $144 \mathrm{~cm}^{2}(12 \mathrm{~cm} \times 12 \mathrm{~cm})$ \\
Number of cells per stack & 70 \\
Number of stacks & 200 \\
Operating temperature & $750^{\circ} \mathrm{C}$ \\
Porosity & $30 \%$ \\
Tortuosity & 2.5 \\
\hline
\end{tabular}

Table A5. Specifications of the secondary components.

\begin{tabular}{ll}
\hline $\begin{array}{l}\text { Pumps } \\
\text { Efficiency }\end{array}$ & 0.95 \\
$\begin{array}{l}\text { Heat exchangers } \\
\text { Effectiveness }\end{array}$ & 0.8 \\
$\begin{array}{l}\text { Compressors } \\
\text { Electro-mechanical efficiency }\end{array}$ & 0.95 \\
$\quad \begin{array}{l}\text { Isoenthropic efficiency } \\
\text { Inverter/ Rectifier }\end{array}$ & 0.7 \\
Efficiency & 0.95 \\
\hline
\end{tabular}

\section{Appendix B: Detailed Modeling of Dish-Stirling}

The $U_{C C}$ is the combined convection-conduction heat loss coefficient accounting for convection to the ambient environment and conduction through the structure. It is calculated as

$$
U_{C C}=\frac{h_{\text {wind }}}{1-U_{\text {sup_ratio }}}
$$

where $U_{\text {sup_ratio }}$ is the loss through the supports of the structure, and $h_{\text {wind }}$ is the heat transfer convection coefficient for wind, and is defined as [23]

$$
\begin{aligned}
& h_{\text {wind }}=\frac{k_{\text {air }}}{D_{\text {rec }}} 0.3 \mathrm{Re}_{\text {wind }}^{0.6} \\
& \operatorname{Re}_{\text {wind }}=\frac{\rho_{\text {air }} V_{\text {wind }} D_{\text {rec }}}{\mu_{\text {air }}}
\end{aligned}
$$

where $k_{\text {air }}, \rho_{\text {air }}$ and $\mu_{\text {air }}$ are the properties of air as conductivity, density, and viscosity, respectively, while $V_{w}$ and $D_{r e c}$ are wind velocity and receiver diameter, respectively.

Finally, the generated power can then be calculated by

$P_{\text {total }}=P_{\text {mech }} \eta_{\text {gen }}-Z_{\text {track }} N_{\text {unit }}$

$$
\eta_{\text {total }}=\frac{P_{\text {mech }}}{\eta_{\text {conc }} \eta_{\text {rec }} \eta_{\text {gen }} Q_{\text {high }}}
$$

where $Z_{\text {track }}$ is the tracking system power. $P_{\text {mech }}$ and $Q_{\text {high }}$ are the power generated by the Stirling 
engine and heat supplied to the engine, respectively.

\section{Appendix C: Detailed Modeling of PTSC-SG}

Friedel correlation [33] assumes that each phase is flowing separately at different velocities and occupying a given fraction of the pipe cross section (separated model).

$$
\Delta p_{2}=\Delta p_{2 p h}=\Delta p_{\text {static }}+\Delta p_{\text {momentum }}+\Delta p_{\text {friction }}
$$

It can be seen that the total pressure drop is divided in three parts: static, momentum and friction pressure drops. The static pressure drop is assumed to be zero because the receiver is placed horizontally. The momentum pressure drop depends on the inlet and outlet states, which assumes the complete evaporation from pure liquid to pure vapor discussed in [33],

$$
\Delta p_{\text {momentum }}=\dot{G}^{2}\left(1-\frac{1}{\rho_{L}}\right)
$$

With the mass velocity $\dot{G}^{2}=\dot{m} / A_{\text {cross }}$, where $A_{\text {cross }}$ is the cross-sectional area of the pipe, and $\dot{m}$ is the mass flow. $\rho_{L}$ is the density of the liquid phase.

The friction factor is calculated based on the pressure drop as if all fluid is in a liquid state. A twophase multiplier is then applied to account for phase changes. The total friction factor depends also on the distance travelled by the fluid, and as the vapor qualities vary along the pipe, the pipe has to be discretized into $N$ segments. The pressure drop in each segment is then calculated individually, and finally, the individual pressure drops are summed to obtain the total pressure drop.

$$
\Delta p_{\text {friction }}=\sum_{z=1}^{N} \Delta p_{L, z} \cdot \phi_{f r, z}^{2}
$$

where the two-phase multiplier is defined as

$$
\phi_{f r, z}^{2}=E_{z}+\frac{3.24 F_{z} H}{F r_{H, z}^{0.045} . W e_{H, z}^{0.035}}
$$

and

$$
E_{z}=\left(1-x_{z}\right)^{2}+x_{z}^{2} \frac{\rho_{L} f_{G}}{\rho_{G} f_{L}}
$$

$$
F r_{H, z}=\frac{\dot{G}^{2}}{g D_{r i} \rho_{H}^{2}}
$$

$$
H=\left(\frac{\rho_{L}}{\rho_{G}}\right)^{0.91}\left(\frac{\mu_{G}}{\mu_{L}}\right)^{0.19}\left(1-\frac{\mu_{G}}{\mu_{L}}\right)^{0.7} \quad \text { and } \quad \rho_{H}=\left(\frac{x_{z}}{\rho_{G}}+\frac{1-x_{z}}{\rho_{L}}\right)^{-1}
$$

where $x_{z}$ is the vapor quality, and $\rho_{G}, \rho_{L}, \mu_{G}, \mu_{L}, f_{G}$ and $f_{L}$ are the densities, viscosities and friction coefficients for the gas and liquid state, respectively. $\psi$ is the surface tension, and $g$ is the gravitational constant. All values are mean values in the segment $z$.

First, the optical efficiency is calculated as follows:

$$
\eta_{o p t}=\varphi \gamma \tau \alpha K_{\gamma \tau \alpha}(\beta)
$$

where $\varphi$ is the specular reflectance, and $\gamma$ is intercept factor. The incidence angle modifier $K_{\gamma \tau \alpha}(\beta)$ is usually correlated from experimental results. Owing to a lack of experimental data for this case, the correlation for a similar unit is used here, as in [23]: 


$$
K_{\gamma \tau \alpha}(\beta)=1-6.47 \times 10^{-5} \beta^{2}+1.64 \times 10^{-6} \beta^{3}-2.51 \times 10^{-8} \beta^{4}
$$

859

860

861

862

863

864

865

866

867

868

869

870

871

872

873

874

875

876

877

878

879

880

881

882

883

884

885

886

887

888

where $\beta$ is the angle of incidence. Then, the mean heat transfer coefficient for the entire PTSC is determined using the total heat loss to the surrounding environment $\left(Q_{\text {loss }}\right)$, assuming a constant mean temperature of the outer surface of the receiver $\left(T_{\text {rom }}\right)$ and a relative coefficient of the conductive losses through the structure compared with the ambient losses $\left(x_{\text {manifold_losss }}\right)$.

$$
U_{L}=\frac{Q_{\text {loss }}}{A_{\text {rec }}\left(T_{\text {rom }}-T_{\text {amb }}\right)} \frac{1}{\left(1-x_{\text {manifold_loss }}\right)}
$$

The manifold loss is assumed to be $20 \%$ of the total loss $\left(x_{\text {manifold_losss }}=0.2\right)$. With the total receiver area $A_{\text {rec }}=\pi D_{\text {ro }} L, T_{\text {rom }}$ is calculated as:

$$
T_{\text {rom }}=T_{\text {rom_1 } 1} \frac{L_{1}}{L}+T_{\text {rom_ } 2} \frac{L_{2}}{L}+T_{r_{\text {rom }} 3} \frac{L_{3}}{L}
$$

where $T_{\text {rom_l }}, T_{\text {rom_ } 2}, T_{\text {rom_ } 3}, L_{1}, L_{2}$ and $L_{3}$ are calculated from the discretization process described above. The total heat loss along the receiver to the surrounding environment is a combination of conduction, convection, and radiation. First, heat is transferred at the air gap between the receiver and the glass cover by radiation and conduction through the quiescent air in the gap. Then, the heat is transferred through the glass cover thickness by conduction, and finally, heat is transferred to surrounding environment radiation and convection. At steady state, there is a heat flux balance in which the temperatures of the boundary layer remain constant and can be determined by solving the following system:

$$
\begin{aligned}
Q_{\text {loss }}= & \frac{2 \pi L k_{e f f}}{\ln \left(\frac{D_{c i}}{D_{r o}}\right)}\left(T_{r o m}-T_{c i}\right)+\frac{\pi D_{r o} L \sigma\left(T_{r o m}^{4}-T_{c i}^{4}\right)}{\frac{1}{\varepsilon_{r}}+\frac{1-\varepsilon_{c}}{\varepsilon_{r}}\left(\frac{D_{r o}}{D_{c i}}\right)} \\
Q_{\text {loss }}= & \frac{2 \pi L k_{c}}{\ln \left(\frac{D_{c o}}{D_{c i}}\right)}\left(T_{c i}-T_{c o}\right) \\
Q_{\text {loss }}= & \pi D_{c o} L h_{w}\left(T_{c o}-T_{a m b}\right)+\varepsilon_{c} \pi D_{c o} L \sigma\left(T_{c o}^{4}-T_{s k y}^{4}\right)
\end{aligned}
$$

where $k_{\text {eff }}$ is the low-pressure air conductivity, and $D_{r o}, D_{c i}$ and $D_{c o}$ are the diameters of the external surface of the receiver, the inner glass cover and external glass cover, respectively. $\varepsilon_{r}$ and $\varepsilon_{c}$ are the emissivity of the receiver and the glass cover, respectively. $k_{c}$ is the conductivity of the glass cover and $h_{w}$ is the convection coefficient of the wind, which can be calculated in the same way as in the case for the Dish-Stirling model. The Stefan-Boltzmann constant is $5.678 \times 10^{-8} \mathrm{~W} /\left(\mathrm{m}^{2} \mathrm{~K}^{4}\right)$.

The effective conductivity of the low-pressure air trapped in the receiver is calculated by [22]

$$
k_{e f f}=\frac{k_{a i r}}{\left(\frac{D_{r o}}{2}\right) \ln \left(\frac{D_{r o}+D_{c i}}{2 D_{r o}}\right)+B \lambda\left(\frac{2 D_{r o}}{D_{r o}+D_{c i}}+1\right)}
$$

$$
\begin{array}{ll}
B=\frac{2-C}{C} \cdot \frac{9 Y-5}{2(Y+1)} & \lambda=2.331 \times 10^{-10} \frac{T_{m}}{p_{m} \Omega^{2}} \\
Y=1.37975268+0.00017703 T_{m}-4.2745 \times 10^{-7} T_{m}^{2}+2.0315 \times 10^{-10} T_{m}^{3}
\end{array}
$$

where $C$ is the accommodation coefficient which has commonly been assumed to be the value of unity $(C=1)$, and $\lambda$ is the mean free path of the molecules. $\Omega$ is the molecular diameter of air, which is $2.32 \times 10^{-8} \mathrm{~m}$, and $T_{m}$ and $p_{m}$ are the mean temperature and pressure in the annulus (gap), respectively. 
The mean temperature at the external surface of the receiver in each section is calculated in order to obtain the $T_{\text {rom }}$ from equation (39). To do that, an energy balance for the pipe wall is performed, resulting in

$$
T_{\text {rom }, s}=T_{f m, s}+\frac{Q_{a b s f_{-} s}}{\pi D_{r o} L_{s} U_{s}} \quad s=1,2 \text { and } 3
$$

where $T_{f m_{-} s}$ is the average temperature of the fluid in section $s$ (see Figure 2), and $U_{s}$ is the overall heat transfer coefficient in section $s$. $U_{s}$ considers the conduction through the pipe wall and convection on the heat transfer fluid side, and is written as

$$
U_{s}=\left[\frac{D_{r o}}{h_{s} D_{r i}}+\frac{D_{r o} \log \left(D_{r o} / D_{r i}\right)}{2 k_{r}}\right]^{-1} \quad s=1,2 \text { and } 3
$$

where $k_{r}$ is the conductivity of the pipe material, and $h_{s}$ is the heat transfer convection coefficient for the fluid side. $h_{s}$ is calculated using different correlations for single-phase and two-phase flows. For the single-phase flow, the Gnielinski correlation is applied, which can be used for a wide range [31], as follows:

$$
h_{s}=\frac{D_{r i}}{k_{s}} \frac{\left(f_{s} / 8\right)\left(\operatorname{Re}_{s}-1000\right) \operatorname{Pr}_{s}}{1+12.7\left(f_{s} / 8\right)^{0.5}\left(\operatorname{Pr}_{s}^{2 / 3}-1\right)}
$$

For two-phase flow (when $s=2$ ), however, the correlation developed by Gungor and Winterton is used [28]. It basically combines the effect of the forced convection and the nucleate boiling weighted with coefficients. Again, similar to the process of calculating the pressure drop in two-phase flow, this section must be discretized into smaller segments because the heat transfer depends on the vapor quality, which varies along the pipe. Thus, the value for $h_{2}$ (two-phase, in the previous equations) is the average value of the $N$ segments defined as

$$
h_{2}=\sum_{Z=1}^{N} h_{2, z}
$$

It was determined that 20 segments were enough for this study. The next step is to calculate the Froude $(F r)$ number [32] in order to distinguish between the flow patterns.

$$
F r=\frac{\dot{G}^{2}}{g D_{r i} \rho_{L}^{2}}
$$

If the $\mathrm{Fr}$ number is lower than 0.04, then stratified flow occurs, and the Shah correlation [33] is then used, as follows:

$$
\begin{aligned}
& \frac{h_{2, z}}{h_{L}}=3.9 F r^{0.24}\left(\frac{x_{z}}{1-x_{z}}\right)^{0.64}\left(\frac{\rho_{L}}{\rho_{G}}\right)^{0.4} \\
& H_{L}=\left(\frac{k_{L}}{D_{r i}}\right) 0.023\left(\frac{\dot{G}\left(1-x_{z}\right) D_{r i}}{\mu_{L}}\right)^{0.8} \operatorname{Pr}^{0.4}
\end{aligned}
$$

where $h_{L}$ is the heat transfer coefficient assuming the liquid fraction that fills the tube and thus the Dittus-Boelter correlation [31] is used. On the other hand, if the $F r$ number is higher than 0.04, then annular flow occurs, and the Chan correlation [33] can be applied, as follows:

$$
\begin{array}{ll}
h_{2, z}=S_{z} h_{B}+F_{z} h_{L, z} & \\
h_{B}=3800\left(\frac{q}{20000}\right)^{n} F_{p} & n=0.9-0.3 p_{r}^{0.15} \\
F_{P}=2.55 p_{n}^{0.27}\left(9+\frac{1}{1-p_{n}^{2}}\right) p_{n}^{2} & p_{n}=\frac{p}{p_{c}}
\end{array}
$$

where $q$ is the heat flux $\left[\mathrm{W} / \mathrm{m}^{2}\right], p$ is the working pressure and $p_{c}$ is the critical pressure $(220.6$ bar 
933

934

935

936

937

938

939

940

941

942

943

944

945

946

947

948

949

950

951

952

953

954

955

[34]). The working pressure is the ratio of the saturated pressure to the critical pressure. It is important to note that, even if there is a pressure drop at the two-phase section (see the calculation above), the pressure for heat transfer calculations is assumed to be constant and equal to the pressure of saturation calculated from the pressure drop in the first section.

Oher coefficients are defined as

$$
\begin{aligned}
& S_{z}=\frac{1}{1+1.15 \times 10^{-6} F_{Z}^{2}\left[\frac{\dot{G}\left(1-x_{z}\right) D_{r i}}{\mu_{L}}\right]^{1.17}} \\
& F_{z}=1+2.4 \times 10^{4} B o^{1.16}+1.37 X_{t t, z}^{-0.86} \\
& X_{t t, z}=\left(\frac{\rho_{G}}{\rho_{L}}\right)^{0.5}\left(\frac{\mu_{G}}{\mu_{L}}\right)^{0.1}\left(\frac{1-x_{z}}{x_{z}}\right)^{0.9}
\end{aligned}
$$

where $B o$ is the boiling number, which is the ratio of mass flux perpendicular to the wall as defined in [28].

Finally, the inlet and outlet temperature of the PTSC are related by the following equation:

$$
Q_{a b s f}=\eta_{\text {opt }} \cdot S \cdot A_{\text {cons }}-U_{L} \cdot A_{\text {rec }}\left(T_{\text {rom }}-T_{a m b}\right)
$$

with $Q_{a b s f}=\dot{m}\left[H_{2}\left(T_{2}, p_{2}\right)-H_{1}\left(T_{1}, p_{1}\right)\right]$, where $H_{1}\left(T_{1}, p_{1}\right)$ and $H_{2}\left(T_{2}, p_{2}\right)$ are the inlet and outlet specific enthalpies, respectively, which are dependent on the temperatures and pressures. $A_{\text {cons }}$ and $A_{\text {rec }}$ are the total areas of the concentrator and receiver, respectively, ( $A_{\text {cons }}=$ aperture $\cdot L$ and $A_{r e c}=\pi D_{r o} L$ ). Table A2 (in the appendix) provides all other parameters for the PTSC-SG.

The surface tension $\psi$ is modeled as a function of saturated temperature as

$$
\psi=0.11993071-0.00013089\left(T_{\text {sat }}+273.15\right)-9.0999 \times 10^{-8}\left(T_{\text {sat }}+273.15\right)^{2}
$$

